\title{
Seasonal and interannual variability in wetland methane emissions simulated by CLM4Me' and CAM-chem and comparisons to observations of concentrations
}

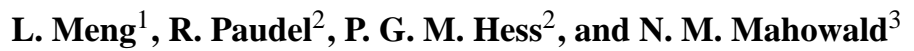 \\ ${ }^{1}$ Department of Geography and Environmental and Sustainability Studies Program, Western Michigan University, \\ Kalamazoo, MI 49008, USA \\ ${ }^{2}$ Department of Earth and Atmospheric Sciences, Cornell University, Ithaca, NY 14850, USA \\ ${ }^{3}$ Department of Biological and Environmental Engineering, Cornell University, Ithaca, NY 14850, USA
}

Correspondence to: L. Meng (lei.meng@wmich.edu)

Received: 11 December 2014 - Published in Biogeosciences Discuss.: 02 February 2015

Revised: 16 April 2015 - Accepted: 08 June 2015 - Published: 03 July 2015

\begin{abstract}
Understanding the temporal and spatial variation of wetland methane emissions is essential to the estimation of the global methane budget. Our goal for this study is three-fold: (i) to evaluate the wetland methane fluxes simulated in two versions of the Community Land Model, the Carbon-Nitrogen (CN; i.e., CLM4.0) and the Biogeochemistry (BGC; i.e., CLM4.5) versions using the methane emission model CLM4Me' so as to determine the sensitivity of the emissions to the underlying carbon model; (ii) to compare the simulated atmospheric methane concentrations to observations, including latitudinal gradients and interannual variability so as to determine the extent to which the atmospheric observations constrain the emissions; (iii) to understand the drivers of seasonal and interannual variability in atmospheric methane concentrations. Simulations of the transport and removal of methane use the Community Atmosphere Model with chemistry (CAM-chem) model in conjunction with CLM4Me' methane emissions from both $\mathrm{CN}$ and BGC simulations and other methane emission sources from literature. In each case we compare model-simulated atmospheric methane concentration with observations. In addition, we simulate the atmospheric concentrations based on the TransCom wetland and rice paddy emissions derived from a different terrestrial ecosystem model, Vegetation Integrative Simulator for Trace gases (VISIT). Our analysis indicates $\mathrm{CN}$ wetland methane emissions are higher in the tropics and lower at high latitudes than emissions from BGC. In $\mathrm{CN}$, methane emissions decrease from 1993 to 2004 while this trend does not appear in the BGC version. In the $\mathrm{CN}$
\end{abstract}

version, methane emission variations follow satellite-derived inundation wetlands closely. However, they are dissimilar in BGC due to its different carbon cycle. CAM-chem simulations with CLM4Me' methane emissions suggest that both prescribed anthropogenic and predicted wetlands methane emissions contribute substantially to seasonal and interannual variability in atmospheric methane concentration. Simulated atmospheric $\mathrm{CH}_{4}$ concentrations in CAM-chem are highly correlated with observations at most of the 14 measurement stations evaluated with an average correlation between 0.71 and 0.80 depending on the simulation (for the period of 1993-2004 for most stations based on data availability). Our results suggest that different spatial patterns of wetland emissions can have significant impacts on Northern and Southern hemisphere $(\mathrm{N}-\mathrm{S})$ atmospheric $\mathrm{CH}_{4}$ concentration gradients and growth rates. This study suggests that both anthropogenic and wetland emissions have significant contributions to seasonal and interannual variations in atmospheric $\mathrm{CH}_{4}$ concentrations. However, our analysis also indicates the existence of large uncertainties in terms of spatial patterns and magnitude of global wetland methane budgets, and that substantial uncertainty comes from the carbon model underlying the methane flux modules. 


\section{Introduction}

The increase in atmospheric methane $\left(\mathrm{CH}_{4}\right)$ concentrations since 2007 (Rigby et al., 2008) has received attention due to methane's strong greenhouse effect. The causes of the renewed increase in $\mathrm{CH}_{4}$ since 2007 and the relative stability of the atmospheric concentrations for the preceding decade (1996-2006) are not well understood (Bloom et al., 2010). Improved understanding of the variability of atmospheric methane can provide more accurate predictions of future concentrations. Changes in atmospheric $\mathrm{CH}_{4}$ are determined by the balance between the emissions of $\mathrm{CH}_{4}$ and its loss. The loss is mostly controlled by the reaction of $\mathrm{CH}_{4}$ with the hydroxyl radical $(\mathrm{OH})$. While the $\mathrm{CH}_{4}$ loss timescale varies from year to year (Wuebbles and Hayhoe, 2002; Bousquet et al., 2006) as the $\mathrm{OH}$ concentration changes, recent evidence suggests the interannual variability of $\mathrm{OH}$ is small (Montzka et al., 2011). The primary sources of atmospheric methane include anthropogenic emissions, natural wetlands, rice paddies, biomass burning, and termites (Denman et al., 2007; Kirschke et al., 2013). Natural wetlands are the largest single source of atmospheric $\mathrm{CH}_{4}$ and make a significant contribution to its variability (Spahni et al., 2011). Using inverse methods, Bousquet et al. (2006) suggests that $70 \%$ of the global emission anomalies $\mathrm{CH}_{4}$ for the period 1984-2003 are due to the interannual variability in wetland emissions and furthermore that tropical methane emissions are the dominant contribution to the global interannual variability. In another methane inversion, Chen and Prinn (2006) find that the large 1998 increase in atmospheric $\mathrm{CH}_{4}$ concentration could be attributed to global wetland emissions.

There are still large uncertainties in global wetland emissions due to (1) poor understanding of environmental and biological processes that control methane emissions (Riley et al., 2011; Meng et al., 2012); and (2) uncertainties in the extent and distribution of wetlands, particularly in tropical regions (Prigent et al., 2007; Spahni et al., 2011). Processbased biogeochemical methane models can help improve the understanding of dominant processes that control methane production, oxidation, and transport. Several process-based models that incorporate different environmental and biological processes have been developed. For instance, Wania et al. (2009) developed the Lund-Potsdam-Jena Wetland Hydrology and Methane (LPJ-WhyMe) model to simulate peatland hydrology and methane emissions from northern latitudes using a mechanistic approach. LPJ-WhyMe was recently incorporated into the Lund-Potsdam-Jena (LPJ) dynamic global vegetation model (DGVM; Spahni et al., 2011) to simulate methane emissions on a global scale by dividing global ecosystems into four different types (northern peatland $\left(45-90^{\circ} \mathrm{N}\right)$, naturally inundated wetlands $\left(60^{\circ} \mathrm{S}-\right.$ $45^{\circ} \mathrm{N}$ ), rice agriculture and wet mineral soils) and using different parameters to characterize the processes relevant for methane production, oxidation, and transport in the soil in each of these ecosystems. Zhuang et al. (2004) couple a methane module to a process-based biogeochemistry model, the Terrestrial Ecosystem Model (TEM), and explicitly calculated methane production, oxidation, and transport in the soil. Xu et al. (2010) include a methane module in the Dynamic Land Ecosystem Model (DLEM) to simulate methane production, oxidation, and transport (Xu et al., 2010). Riley et al. (2011) integrate a methane biogeochemical model (CLM4Me) into the Community Land Model (CLM), the land component of the Community Climate System Models (Gent et al., 2011) and the Community Earth System Model (CESM). Meng et al. (2012) add additional features into CLM4Me including an emission dependence on $\mathrm{pH}$ and on redox potential. This revised version of CLM4Me is referred to as CLM4Me' (Meng et al., 2012). Detailed description of CLM4Me and CLM4Me' can be found in Riley et al. (2011) and Meng et al. (2012). The large uncertainties in methane fluxes due to parameter uncertainty in this model are quantified in Riley et al. (2011).

These process-based models are often evaluated against surface $\mathrm{CH}_{4}$ flux measurements based on chamber techniques (Jauhiainen et al., 2005; Shannon and White, 1994; Keller, 1990). However, there are only limited observational data sets available for model evaluation and most of them are in mid- and high latitudes. The shortage of tropical methane measurements makes it difficult to evaluate the spatial distribution of modeled surface emissions. This is especially critical as the tropical wetlands are the largest contribution to global wetland methane emissions (Meng et al., 2012; Spahni et al., 2011; Bloom et al., 2010).

The spatial distribution of surface emissions produced by these biogeochemical models can be used along with other $\mathrm{CH}_{4}$ emission sources as inputs to atmospheric chemistry and transport models to simulate atmospheric $\mathrm{CH}_{4}$ concentration. As wetland emissions are the largest single source, their spatial distribution could significantly affect the distribution of atmospheric $\mathrm{CH}_{4}$ concentration. The long-term atmospheric measurement of $\mathrm{CH}_{4}$ can be used to compare with modeled atmospheric $\mathrm{CH}_{4}$ to further evaluate the spatial distribution of surface emissions. Recently, a chemistry-transport model (CTM) intercomparison experiment (TransCom- $\mathrm{CH}_{4}$ ) quantifies the role of $\mathrm{CH}_{4}$ surface emission distributions in simulating the global distribution of atmospheric methane (Patra et al., 2011). In TransCom$\mathrm{CH}_{4}, 12$ chemistry-transport models simulations with different surface emissions are evaluated against measured atmospheric $\mathrm{CH}_{4}$ concentrations. Patra et al. (2011) find that meteorological conditions and surface emissions from biomass burning and wetlands can contribute up to $60 \%$ of the interannual variation (IAV) in the atmospheric $\mathrm{CH}_{4}$ concentrations. However, in Patra et al. (2011), the methane emissions are specified and do not result from interactions between simulated meteorology and land-carbon models.

In this study, we explore the temporal and spatial variation of wetland methane emissions estimated in CLM4Me'. The modeled wetland emissions are used with other surface 


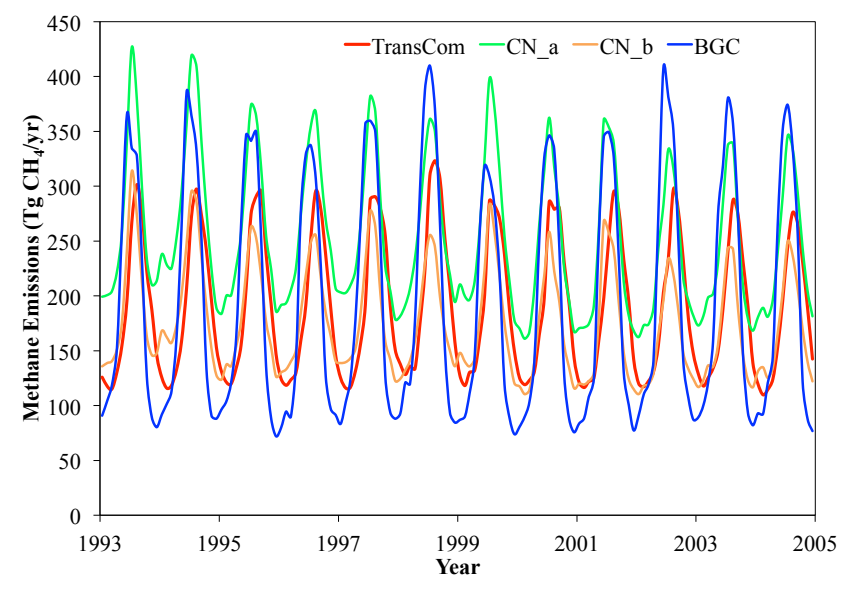

Figure 1. Comparison of the time series of combined methane emissions from wetlands and rice paddies used in the TransCom (Patra et al., 2011), CN_a, CN_b, and BGC experiments. Note that the average methane budget over the period of 1993-2004 is the same in the TransCom, CN_a, CN_b, and BGC experiments. CN_b is the reduced CN_a.

emissions (including emissions from anthropogenic sources, biomass burning, rice paddies, and termites) as inputs to the Community Atmospheric Model with chemistry (CAMchem). The $\mathrm{CH}_{4}$ concentration simulated with CAM-chem is compared with a global network of station measurements. The purposes of this paper are (1) to examine seasonal and interannual variations in wetland methane emissions simulated by CLM4Me' in two different versions of the Community Land Model; (2) to compare the simulated atmospheric methane concentrations to observations, including latitudinal gradients and interannual variability so as to determine the extent to which the atmospheric observations constrain the emissions; (iii) to understand the drivers of seasonal and interannual variability in atmospheric methane fluxes. Section 2 describes models, methods, and data sets. Results and discussions are presented in Sect. 3. We conclude in Sect. 4 with a summary of major findings.

\section{Models and data sets}

\subsection{Simulations}

Methane emissions from 1993 to 2004 are simulated and analyzed in four different model configurations (see Table 1). All configurations use Community Atmospheric Model (CAM4) with chemistry (CAM-chem) (Lamarque et al., 2012) to diagnose atmospheric methane. These configurations differ in their specification of methane emissions. Other details of the simulations are identical.

The TransCom simulation (Table 1) is reported on as part of the TransCom- $\mathrm{CH}_{4}$ simulations (Patra et al., 2011). CAMchem is one of the 12 models participating in these sim-

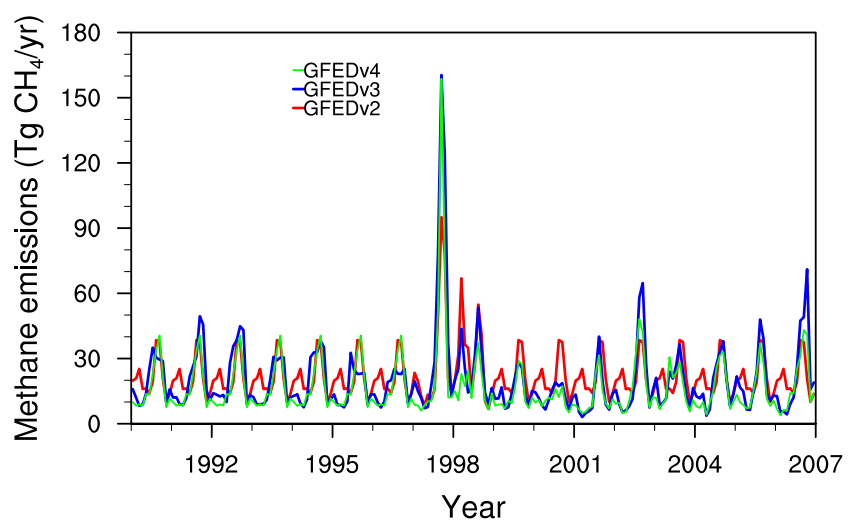

Figure 2. Comparison of the interannual variation in methane emissions from fire in the GFED v2 (van der Werf et al., 1996), GFED v3 (Gilglio et al., 2010), and GFED v4 (van der Werf et al., 2010). These data sets are obtained from http://www.globalfiredata.org/.

ulations (Patra et al., 2011). The methane emissions in the TransCom are specified and included the seasonal variation of methane emissions from anthropogenic sources (Olivier and Berdowski, 2001), rice paddies and wetlands (Ito and Inatomi, 2012), biomass burning (van der Werf et al., 2006), and termites (Fung et al., 1991). The wetland emissions from Ito and Inatomi (2012) are calculated based on a processbased terrestrial ecosystem model, the Vegetation Integrative Simulator for Trace gases (VISIT). In the VISIT, the inundated area is calculated based on model-derived rainfall and temperature (Mitchell and Jones, 2005). We select this scenario from the TransCom experiment because it includes the long-term monthly variations of wetland and rice paddy emissions.

Differences between the TransCom simulation and the other three simulations analyzed here (see Table 1) include (1) differences in the specification of the methane emissions from rice paddies and wetlands: in the TransCom simulation the emissions are specified while in the remaining three simulations the methane emissions are obtained from CLM4Me a process-based methane biogeochemical model; (2) differences in the specification of fire emissions: in the TransCom simulation, fire emissions are taken from the Global Fire Emission Database (GFED) v2 (on average $20 \mathrm{Tg} \mathrm{CH}_{4} \mathrm{yr}^{-1}$ is emitted) (van der Werf et al., 2006) while in the remaining three simulations, the fire emissions are from GFED v3 (on average $21.1 \mathrm{Tg} \mathrm{CH}_{4} \mathrm{yr}^{-1}$ is emitted) (Giglio et al., 2010). The current version, GFED v4, has an average $\mathrm{CH}_{4}$ emission of $15.7 \mathrm{Tg} \mathrm{CH}_{4} \mathrm{yr}^{-1}$ (van Der Werf et al., 2010) which is much lower than GFED version 2 and version 3 (Fig. 2). Please note that GFED version 4 was not used in this study.

Two of the configurations analyzed (labeled CN_a and CN_b) diagnose wetlands and rice paddies methane emissions using CLM4Me' within the Community Land Model version 4 (CLM4 or CLM-CN) of the Community Earth System Model (CESM); one configuration (labeled BGC) uses 
Table 1. Comparison of the methane sources in the four simulations used in this study.

\begin{tabular}{lllll}
\hline Input Data & TransCom & CN_a & CN_b & BGC \\
\hline Anthropogenic emissions & OB2001 ${ }^{1}$ & $0.72 \cdot$ OB2001 & OB2001 & OB2001 \\
Wetland emissions & Ito and Inatomi (2012) & CLM4.0 & $0.64 \cdot$ CLM4.0 & $0.74 \cdot$ CLM4.5 \\
Rice paddy emissions & Ito and Inatomi (2012) & CLM4.0 & CLM4.0 & CLM4.5 \\
Termite emissions & Fung et al. (1991) & Fung et al. (1991) & Fung et al. (1991) & Fung et al. (1991) \\
Fire emissions & GFED v2 & GFED v3 & GFED v3 & GFED v3 \\
\hline
\end{tabular}

${ }^{1} \mathrm{OB} 2001$ refers to the anthropogenic methane emissions in Olivier and Berdowski (2001). The average annual $\mathrm{CH}_{4}$ emissions are $\sim 294 \mathrm{Tg} \mathrm{yr}^{-1} \mathrm{over}$ the period of 1993-2004. ${ }^{2}$ CLM4.0 refers to the methane emissions estimate in the CLM4.0 model as used in Meng et al. (2012). The average annual methane emissions were $\sim 228 \mathrm{Tg} \mathrm{yr}^{-1}{ }^{3}$ CLM4.5 refers to the methane emissions estimated in the CLM4.5 model. The estimated annual methane emissions from CLM4.5 were $\sim 190 \mathrm{Tg} \mathrm{yr}^{-1}$ over the period of 1993-2004. ${ }^{4}$ GFED indicates the Global Fire Emission Database. Average annual $\mathrm{CH}_{4}$ emissions from GFED v2 and v3 are $\sim 20$ and $\sim 21 \mathrm{Tg} \mathrm{yr}^{-1}$, respectively. ${ }^{5}$ Wetland and rice paddy emissions from Ito and Inatomi (2012) were downscaled to approximately $183 \mathrm{Tg} \mathrm{yr}^{-1}$ over the period of 1993-2004 for TransCom. CLM4.0 rice paddy emissions are $37 \mathrm{Tg} \mathrm{yr}^{-1}$. CLM4.5 rice paddy emissions are $42 \mathrm{Tg} \mathrm{yr}^{-1}$. Termite emissions from Fung et al. (1991) are $20 \mathrm{Tg} \mathrm{yr}^{-1}$. Note that the global total averaged emissions for the study period used in the TransCom, CN_a, and CN_b, BGC are the same (within $1 \%$ variation), but the spatial distribution of methane emissions might be different.
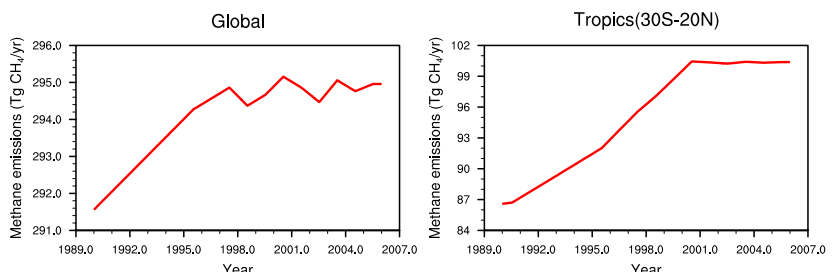

Mid-latitude(20N-50N)
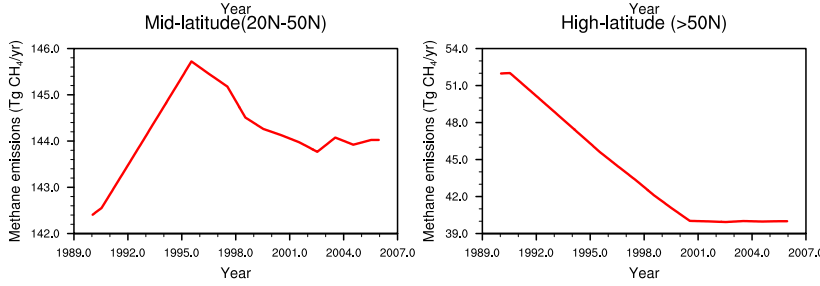

Figure 3. The interannual anthropogenic methane emissions over the globe, in the tropics, mid-latitudes, and high latitudes. These data sets are obtained from TransCom (Patra et al., 2010)

CLM4Me' within the Community Land Model version 4.5 (CLM4.5 or CLM-BGC) of the CESM.

The wetland emissions simulated by CLM4Me' model when integrated in CLM4.0 (228 $\left.\mathrm{Tg} \mathrm{yr}^{-1}\right)$ are on the high side of current estimates (100-284 $\mathrm{Tg} \mathrm{yr}^{-1}$ ) (Denman et al., 2007; Kirschke et al., 2013). In order to obtain a reasonable overall methane budget $\left(\sim 517 \mathrm{Tg} \mathrm{yr}^{-1}\right.$, within the range of $492-581 \mathrm{Tg} \mathrm{yr}^{-1}$ shown in Denman et al. (2014) and Kirschke et al. (2013)), we adjust the emissions in the simulations using CLM4.0. In simulation CN_a, the anthropogenic emissions used in the TransCom simulations are multiplied by 0.72 ; in simulation CN_b the wetland emissions are multiplied by 0.64 , but the anthropogenic emissions are the same as those in TransCom. Both these re-scalings retain the temporal and spatial emission distributions from the original data sets but simulate the approximately correct atmospheric methane concentrations. In the first case (CN_a), where anthropogenic emissions are reduced, the total anthropogenic emissions are $211 \mathrm{Tg} \mathrm{yr}^{-1}$. This is at the low end of estimated anthropogenic emissions, but within the range (209-273 Tg) of values reported in the literature (see IPCC AR4 Chapter 7) (Denman et al., 2007; Kirschke et al., 2013) when excluding biomass burning and rice paddies.

On the other hand, the wetland emissions simulated by CLM4Me' model integrated into CLM4.5 (BGC) are higher than CLM4.0 (CN) emissions. Therefore, we adjust the wetland emissions in the BGC simulation. In particular, in the BGC simulation the wetland emissions are reduced by $26 \%$ to match the total methane emissions in the other simulations. Reducing the methane emissions is equivalent to modifying the coefficient for the maximum amount of methane that can be produced from heterotrophic respiration. The reductions used here are within the uncertainties of this estimate (e.g., Riley et al., 2011). The same termite emissions are used in all simulations. The global interannual average of methane emissions used in CN_a, CN_b, and BGC are similar to that used in TransCom.

\subsection{CLM4Me'}

CLM4Me' (Meng et al., 2012) is a process-based methane biogeochemical model incorporated in CLM version 4 and CLM version 4.5 of the Community Earth System Model (CESM). The spatial resolution used in this study is $1.8 \times 2.5$ degree. CLM4Me' is based on CLM4Me (Riley et al., 2011) and explicitly calculates methane production, methane oxidation, methane ebullition, methane diffusion through soils, and methane transport through aerenchyma. CLM4Me' is an update of CLM4Me to include $\mathrm{pH}$ and redox functional dependence for methane emissions, and a limitation of aerenchyma in plants in always-inundated areas (Meng et al., 2012). In CLM4Me', methane production $\left(P\left(\mathrm{~mol} \mathrm{C} \mathrm{m}^{-2} \mathrm{~s}^{-1}\right)\right)$ is calculated as follows:

$P=R_{\mathrm{H}} f_{\mathrm{CH}_{4}} Q_{10}^{\prime} S f_{\mathrm{pH}} f_{\mathrm{pE}}$ 


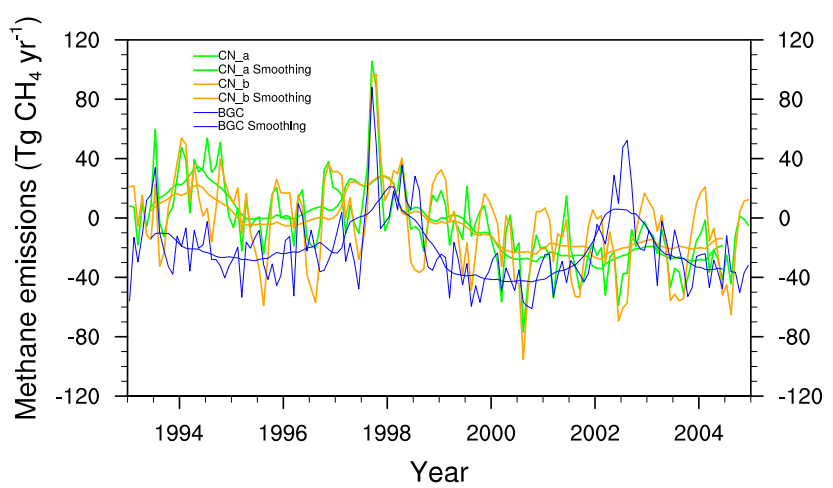

Figure 4. The difference in total emissions used in CN_a, CN_b, BGC experiments as compared with TransCom. A 12-month smoothed average is also plotted for the difference of CN_a (CN_a - TransCom), CN_b (CN_b - TransCom), BGC (BGC - TransCom) with TransCom. Please note that the average of the difference in the period of 1993-2004 is zero.
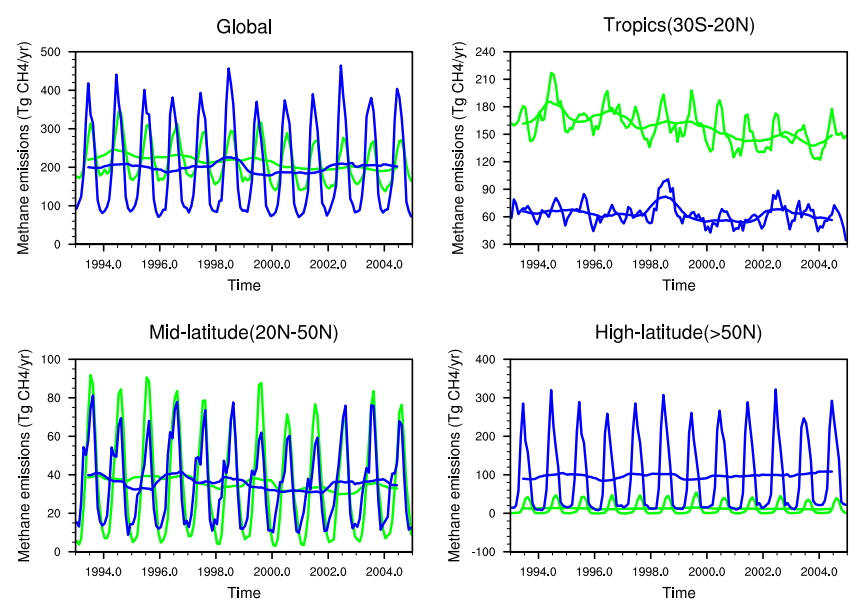

Figure 5. Temporal variation of wetland $\mathrm{CH}_{4}$ fluxes estimated in CN_a (green) and BGC (blue). The globe is divided into three regions: the tropics $\left(30^{\circ} \mathrm{S}\right.$ to $\left.20^{\circ} \mathrm{N}\right)$, mid-latitudes $\left(20-50^{\circ} \mathrm{N}\right)$, and high latitudes $\left(>50^{\circ} \mathrm{N}\right)$. Please note that this is the original methane emissions produced by $\mathrm{CN} \_$a and BGC without any multiplication. The smooth green and blue lines indicate the 12-month average wetland $\mathrm{CH}_{4}$ fluxes for $\mathrm{CN} \_$a and BGC.

Here, $R_{\mathrm{H}}$ is heterotrophic respiration from soil and litter $\left(\mathrm{molC} \mathrm{m}{ }^{-2} \mathrm{~s}^{-1}\right), f_{\mathrm{CH}_{4}}$ is the ratio between $\mathrm{CO}_{2}$ and $\mathrm{CH}_{4}$ production, which is currently set to 0.2 for wetlands and rice paddies. $Q_{10}^{\prime}$ is the control of soil temperature on $\mathrm{CH}_{4}$ production. $f_{\mathrm{pH}}$ and $f_{\mathrm{pE}}$ are $\mathrm{pH}$ and redox potential function, respectively. A detailed description of CLM4Me and CLM4Me' can be found in Meng et al. (2012) and Riley et al. (2011).

\subsection{Community Land Model (CLM)}

CLM4Me' is integrated and spun up in two versions of CLM: CLM4.0 and CLM4.5. CLM4.0 uses the carbon and nitrogen belowground module from the Carbon-Nitrogen $(\mathrm{CN})$ model (Thornton et al., 2007, 2009). CLM4.5 is updated from CLM4.0 and offers some improvements, with the most significant change to the belowground carbon cycle (Koven et al., 2013). CLM4.5 includes an alternate decomposition cascade from the Century soil model, which is referred to as the biogeochemistry version of the model (CLM4.5-BGC). This version of the model has increased productivity and carbon at high latitudes (perhaps an overestimate) and reduced productivity in the tropics compared to the $\mathrm{CN}$ model (see Koven et al. (2013) for more comparisons). The initial condition in both CLM models is created using NCEP reanalysis data sets in two steps. First the model is brought close to equilibrium for 1850 conditions (atmospheric $\mathrm{CO}_{2}$ concentration, aerosol deposition, nitrogen deposition, and land use change) cycling a 25-year (1948-1972) subset of transient climate data (1948-2004). Then we use these equilibrated conditions in a transient simulation from 1850 to 1990 (where the meteorology is cycled over the period of 1948 2004) to produce the initial condition used in this study. For the period of this study (1990-2005), CLM4Me' is forced with multi-satellite-derived inundation fraction (Prigent et al., 2007) and NCEP (i.e., the National Center for Environmental Prediction) reanalysis data sets (Qian et al., 2006; Kistler et al., 2001). While the simulation period is 19902005, satellite-derived inundation data is only available from 1993 to 2004 . We use climatological monthly average (19932004) inundation fraction for years 1990-1992 and 2005.

\subsection{CAM-chem}

We use CAM-chem (Lamarque et al., 2012), driven by the NCEP reanalysis data set (Kistler et al., 2001; Qian et al., 2006) to predict the atmospheric concentrations of methane from the methane emissions. In this study, we conduct simulations with CAM-chem using offline meteorological forcing, similar to the model setup used in TransCom (Patra et al., 2011). The simulations are performed at a horizontal resolution of $1.9^{\circ}$ (latitude) and $2.5^{\circ}$ (longitude) and at 28 vertical layers. Please refer to Lamarque et al. (2012) for a detailed description of CAM-chem.

In the CAM-chem version used here, the atmospheric chemistry is simplified compared to Lamarque et al. (2012), and includes only the reactions necessary to capture the loss of methane. The simulations include the chemical removal reactions for $\mathrm{CH}_{4}$ including the reaction with $\mathrm{OH}$, the excited atomic oxygen $\left(\mathrm{O}^{1} \mathrm{D}\right)$, and chlorine $(\mathrm{Cl})$. Specifics of the chemical loss reactions can be found in Patra et al. (2011). Interannually constant monthly mean $\mathrm{OH}$ is used in the CAMchem simulations. The optimized $\mathrm{OH}$ derived from $\mathrm{CH}_{3} \mathrm{CCl}_{3}$ concentrations scaled from Spivakovsky et al. (2000) is used 

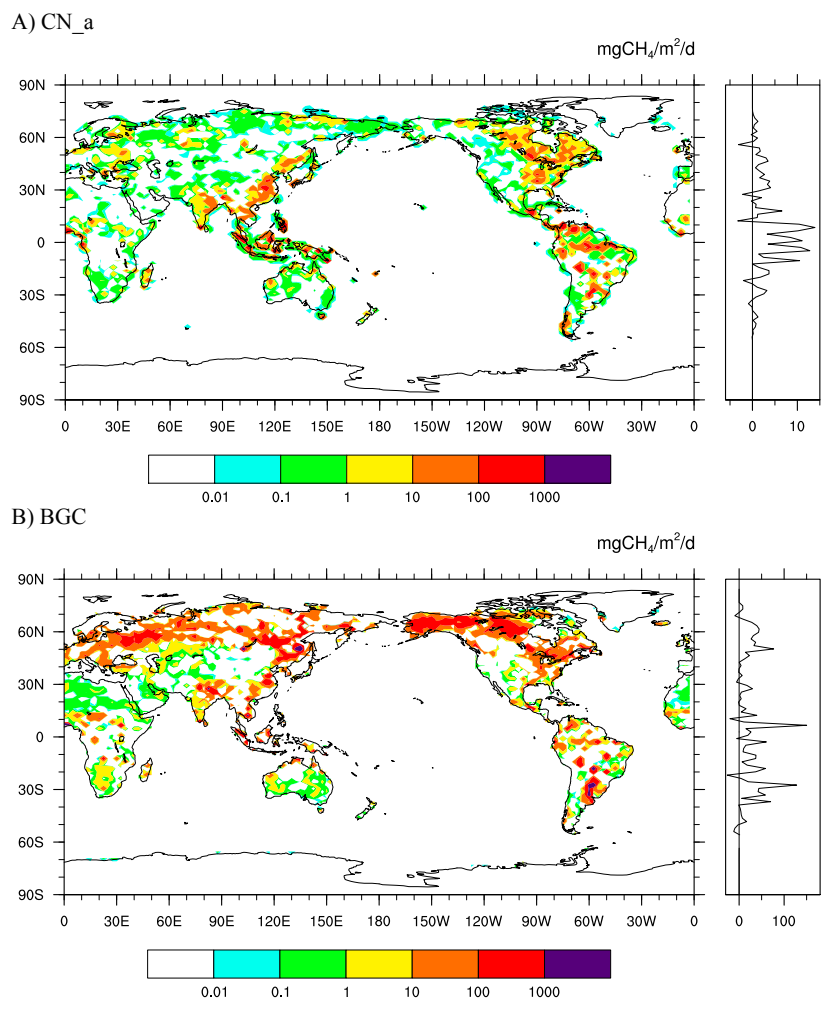

Figure 6. The spatial difference in $\mathrm{CH}_{4}$ fluxes between four high and low emission years. Please note $\mathrm{CH}_{4}$ fluxes are plotted on a logarithmic color scale in CN_a (top, a) and BGC (bottom, b). The latitudinal average $\mathrm{CH}_{4}$ flux is plotted on the right.

where an equal $\mathrm{OH}$ abundance is assumed in both the Northern and Southern hemispheres. The distribution of $\mathrm{OH}$ used to compute the loss of atmospheric methane is identical to that used in TransCom experiments. Stratospheric loss due to $\mathrm{Cl}$ and $\mathrm{O}^{1} \mathrm{D}$ is also included. Interannually constant monthly $\mathrm{Cl}$ and $\mathrm{O}^{1} \mathrm{D}$ are used in the simulations. In addition, a soil sink for $\mathrm{CH}_{4}$ is included using a climatological monthly average derived from LMDZ (Laboratoire de Météorologie Dynamique Zoom) atmospheric $\mathrm{CH}_{4}$ inversion (Bousquet et al., 2006).

Atmospheric concentrations of methane are tagged from rice paddy, wetland, anthropogenic, and biomass burning emission sources. The losses of tagged methane are identical to those described above.

\subsection{Observed atmospheric $\mathrm{CH}_{4}$ concentration.}

Observational atmospheric $\mathrm{CH}_{4}$ concentration data sets are obtained from the World Data Centre for Greenhouse Gases (WDCGG) at http://ds.data.jma.go.jp/gmd/wdcgg/. Monthly concentration data sets from 14 stations (Table 2) around the world are compared with the simulated atmospheric $\mathrm{CH}_{4}$ (Butler et al., 2004; Cunnold et al., 2002). Most of the sites have monthly or weekly measurements and use

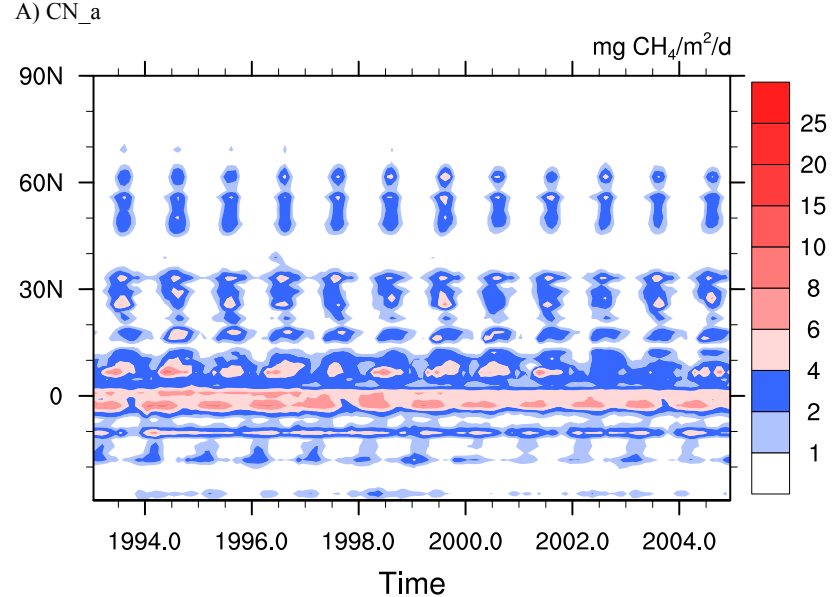

B) BGC

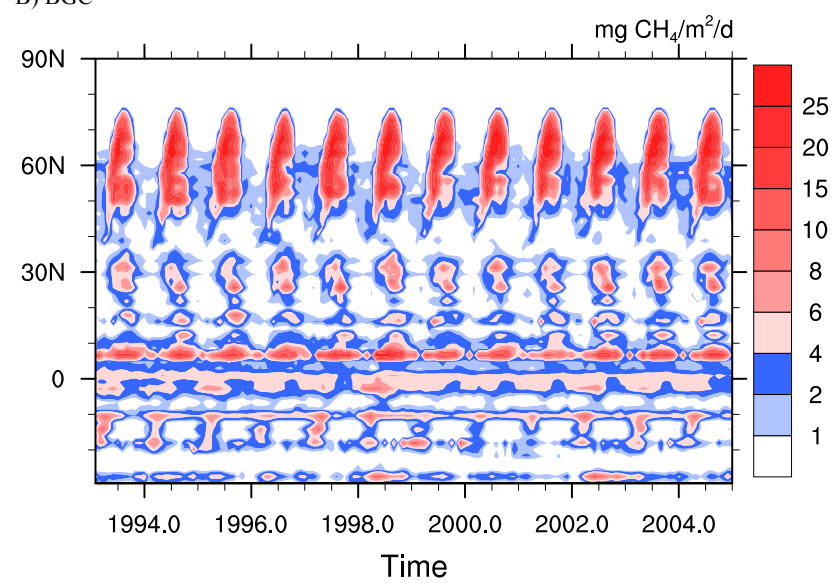

Figure 7. Zonal average monthly methane fluxes with time in CN_a (top, a) and BGC (bottom, b) experiments.

the flask-sampling method. Collected samples are analyzed using gas chromatography with flame ionization detection (Dlugokencky et al., 2005).

\subsection{RMS Variability}

Seasonal and interannual root mean square (RMS) variability are used to evaluate the spatial distribution of simulated methane variability. We apply the method described in Nevison et al. (2008). Here, seasonal RMS variability is calculated as the RMS of the differences between model climatological monthly means (1990-2004) and the climatological annual mean. The interannual variability of RMS is calculated as the RMS of the differences between each month and the corresponding month from the climatological seasonal cycle. We calculate RMS separately for methane tagged from each tagged emission source. This apportions the variability of each source by calculating the ratio between the variability due to that source's RMS and the total RMS. Please note that the sum of individual source's contribution to total RMS is 
Table 2. A list of stations used in this study.

\begin{tabular}{llrrrl}
\hline Station no. & Station name & Lat & Lon & Elevation (m) & Data availability \\
\hline 1 & South Pole (USA) (spo) & -89.98 & $24.80^{\circ} \mathrm{W}$ & 2810 & Feb 1983 to present \\
2 & Cape Grim (Australia) (cgo) & -40.68 & $144.68^{\circ} \mathrm{E}$ & 94 & Jan 1984 to present \\
3 & Tutuila (Cape Matatula) (smo) & -14.24 & $170.57^{\circ} \mathrm{W}$ & 42 & Apr 1983 to present \\
4 & Ascension Island (UK) (asc) & -7.92 & $14.42^{\circ} \mathrm{W}$ & 54 & May 1983 to present \\
5 & Cape Kumukahi (USA) (kum) & 19.52 & $154.82^{\circ} \mathrm{W}$ & 3 & Apr 1983 to present \\
6 & Mauna Loa (USA) (mlo) & 19.54 & $155.58^{\circ} \mathrm{W}$ & 3397 & May 1983 to present \\
7 & Mt. Waliguan (China) (wlg) & 36.28 & $100.90^{\circ} \mathrm{E}$ & 3810 & May 1991 to present \\
8 & Tae-ahn Peninsula (S. Korea) (tap) & 36.72 & $126.12^{\circ} \mathrm{E}$ & 20 & Mar 1993 to present \\
9 & Niwot Ridge (USA) (nwr) & 40.05 & $105.59^{\circ} \mathrm{W}$ & 3523 & Jun 1983 to present \\
10 & Mace Head (Ireland) (mhd) & 53.33 & $9.90^{\circ} \mathrm{W}$ & 8 & Jun 1991 to present \\
11 & Cold Bay (USA) (cba) & 55.2 & $162.72^{\circ} \mathrm{W}$ & 25 & May 1983 to present \\
12 & Barrow (USA) (brw) & 71.32 & $156.60^{\circ} \mathrm{W}$ & 11 & Jan 1986 to present \\
13 & Zeppelinfjellet (Norway) (zep) & 78.9 & $11.88^{\circ} \mathrm{E}$ & 475 & May 1994 to present \\
14 & Alert (Canada) (alt) & 82.45 & $62.52^{\circ} \mathrm{W}$ & 210 & Jun 1985 to present \\
\hline
\end{tabular}

often greater than 1 in cases of cancelation of signals among individual sources.

\subsection{Taylor diagrams}

Taylor diagrams can provide a concise statistical summary of model performance in a single polar coordinate plot (Taylor, 2001). In this study, we use Taylor diagrams to evaluate the model's ability to simulate the observed interannual variability (IAV) of atmospheric $\mathrm{CH}_{4}$. The Taylor diagram gives the model-measurement coefficient $R$ reflecting the agreement in shape and phasing of the model and measurement time series and the ratio of modeled to measured standard deviation $\sigma_{\text {model }} / \sigma_{\text {obs }}$, which represents the agreement between the amplitude of the simulated and observed interannual variability (IAV) of atmospheric $\mathrm{CH}_{4}$.

\section{Results and discussions}

\subsection{Comparison of methane fluxes from different sources}

A comparison of methane fluxes used in the four experiments shows that wetlands and rice paddies methane emissions in CN_a are higher than those used in other three simulations (Fig. 1). Emissions from wetlands and rice paddies in the CN_b (i.e., the CN_a wetland emissions reduced by $36 \%$ ) simulations are comparable with those used in TransCom and BGC experiments (Fig. 1). There are different magnitudes in the seasonal and interannual variations among these four experiments. Overall, BGC has the lowest winter emissions. There is a decreasing trend in the CN_a and CN_b methane emissions not evident in the TransCom and BGC methane emissions. The difference in methane emissions in CN_a, CN_b, and BGC experiments will be discussed in the next session. The fire emissions in the TransCom simulation (based on GFED v2) and the other simulations (based on GFED v3) (Fig. 2) are similar in magnitude, but with some distinct seasonal differences.

Overall, the anthropogenic methane emissions tend to stabilize after 1998, due to the decrease from mid- and high latitudes (Fig. 3). The annual total methane emissions used in CN_a and CN_b experiments are slightly higher (lower) than that used in TransCom experiment during the first (second) half of the study period (Fig. 4). The annual total emissions used in BGC are slightly lower than those used in TransCom during most years except 1997, 1998, and 2002. There are no statistically significant trends (at $~ 95 \%$ level) in the difference between the BGC and TransCom total emissions.

\subsection{Seasonal and interannual variability in $\mathrm{CN}$ _a and BGC methane emissions}

\subsubsection{CN_a methane emissions}

There are strong seasonal and interannual variations in CN_a wetland methane emissions (Fig. 5). On a seasonal basis, the peak methane emissions occur in the summer (June, July, and August) and the lowest methane emissions occur in winter (December, January, and February) as methane emissions are controlled by both temperatures and inundated area. On an interannual basis, the summer of 1994 has the highest CN_a methane emissions methane emissions in the period of 1993 2004. A generally decreasing trend $\left(-2.1 \mathrm{Tg} \mathrm{CH}_{4} \mathrm{yr}^{-1}\right.$, significant at $95 \%$ level) in CN_a global wetland emissions occur from 1994 to 2004 . This is driven by trends in tropical wetland emissions (Fig. 5), where tropical wetlands contribute to $\sim 70 \%$ of the global wetland flux. The decreasing rate in tropical wetland emissions from 1993 to 2004 is approximately $-1.68 \mathrm{Tg} \mathrm{CH}_{4} \mathrm{yr}^{-1}$, statistically significantly different from 0 (no change) at the $95 \%$ confidence level.

We further identify the four highest (1994, 1995, 1996, 1999) and lowest $(2001,2002,2003,2004)$ annual CN_a 

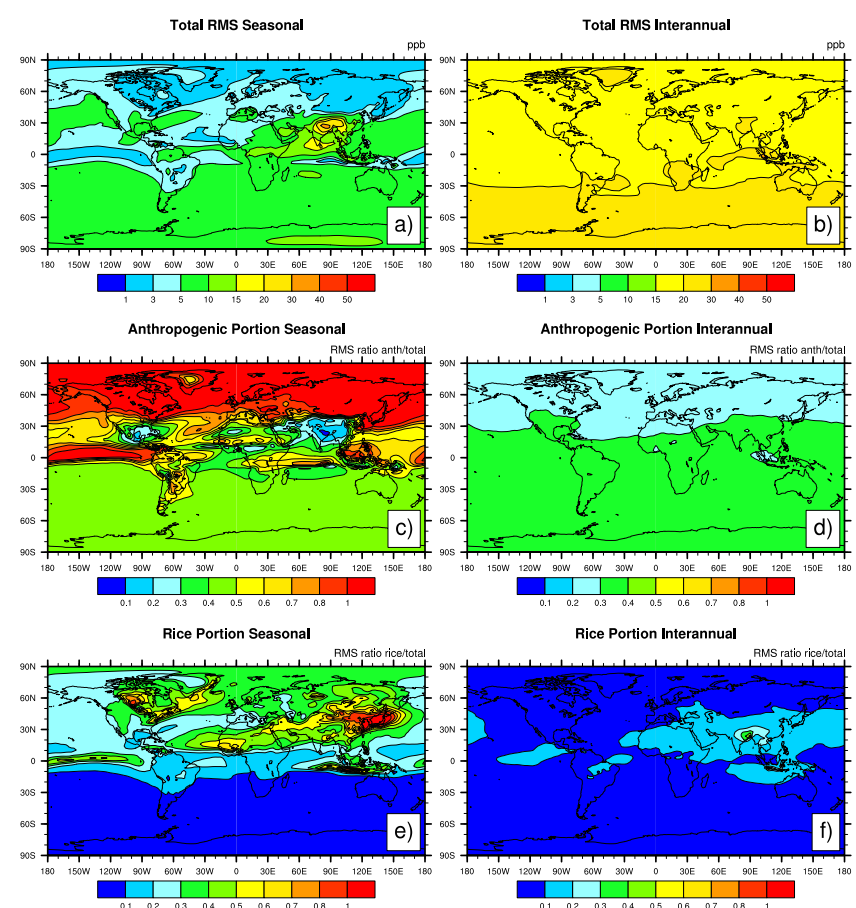

Wetlands Portion Season
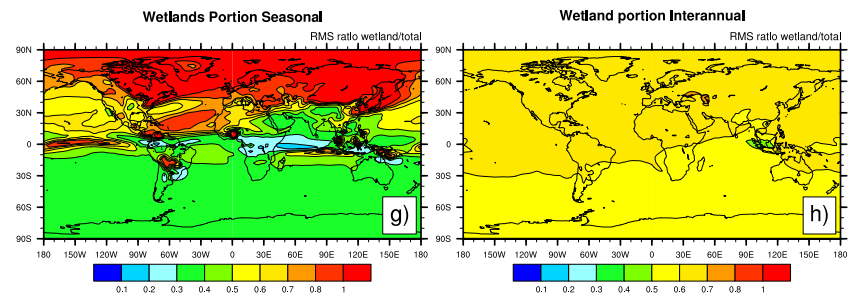

Figure 8. RMS variability (in ppb) from 1993 to 2004 of atmospheric $\mathrm{CH}_{4}$ concentration in $\mathrm{CN} \_$a experiment. The left panel shows seasonal RMS variability and the right panel indicates interannual RMS variability. From the top to the bottom are total RMS variability $(\mathbf{a}, \mathbf{b})$, anthropogenic contribution to total RMS variability $(\mathbf{c}, \mathbf{d})$, rice contribution to total RMS variability (e, f), and wetland contribution to RMS variability $(\mathbf{g}, \mathbf{h})$. Note that proportional RMS variability of anthropogenic sources, rice paddies, and wetlands add up to $>1$ when cancellation among component tracers occurs in the summing of total $\mathrm{CH}_{4}$.

methane emissions in the period of 1993-2004 and plot the difference of methane emissions between the average of these four extreme high and low emission years (Fig. 6a). There are large differences across much of the globe, but the largest difference occurs in the tropics (see the latitudinal average on the right side of Fig. 6a). On a regional level, the largest differences are primarily present in Indonesia and South America (e.g., the Amazon regions).

\subsubsection{BGC methane emissions}

The trend in BGC wetland methane emissions is different from that in CN_a experiment (Fig. 5). In the BGC simulation, the peak emissions occur in 2002 instead of 1994. The
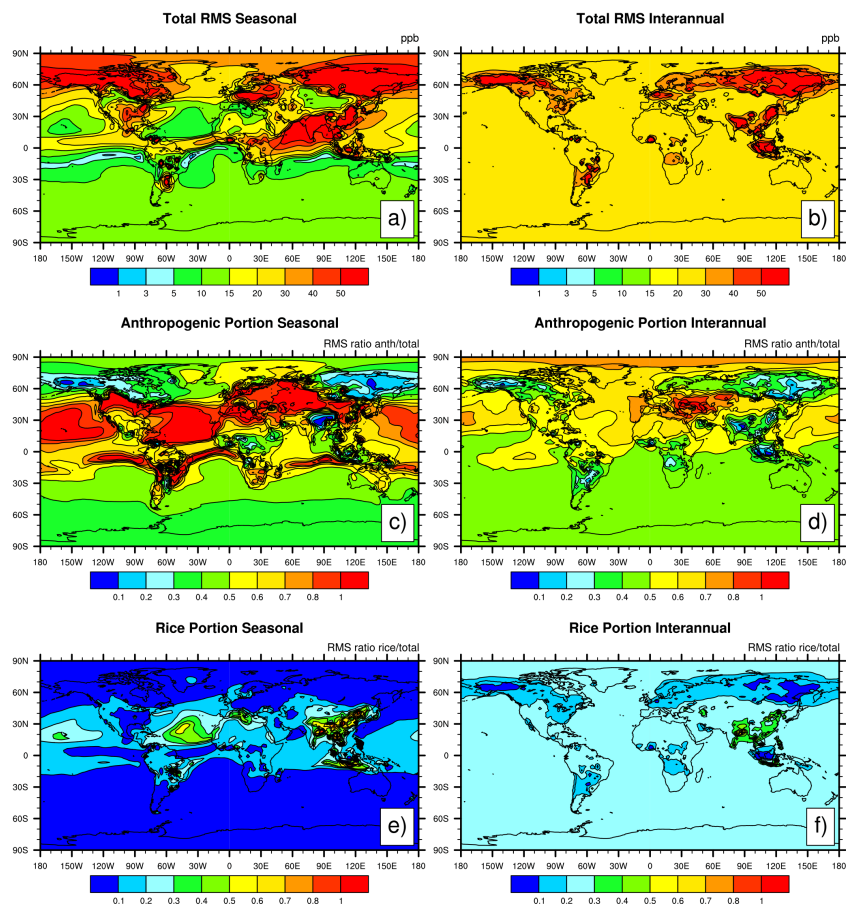

Wetlands Portion Seasona
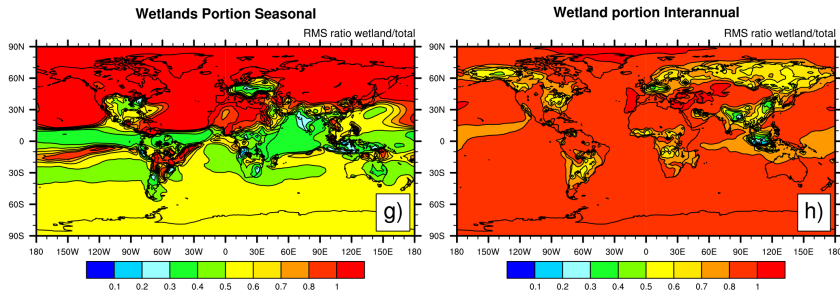

Figure 9. RMS variability (in ppb) from 1993 to 2004 of atmospheric $\mathrm{CH}_{4}$ concentration in BGC experiment. The left panel shows seasonal RMS variability and the right panel indicates interannual RMS variability. From the top to the bottom are total RMS variability $(\mathbf{a}, \mathbf{b})$, anthropogenic contribution to total RMS variability $(\mathbf{c}, \mathbf{d})$, rice contribution to total RMS variability $(\mathbf{e}, \mathbf{f})$, and wetland contribution to RMS variability $(\mathbf{g}, \mathbf{h})$. Note that the portions of RMS variability of anthropogenic sources, rice paddies, and wetlands add up to $>1$ when cancellation among component tracers occurs in the summing of total $\mathrm{CH}_{4}$.

wetland emissions do not decrease significantly from 1993 to 2004 with no significant trends in the interannual methane emissions in the mid- and high latitudes and the tropics in these simulations. There are several additional differences between CN_a and BGC wetland emissions: (1) global BGC wetland emissions are approximately $10 \%$ lower than CN_a wetland emissions; (2) the BGC tropical $\left(-30^{\circ} \mathrm{S}\right.$ to $20^{\circ} \mathrm{N}$ ) wetland emissions of $63 \mathrm{Tg} \mathrm{CH}_{4} \mathrm{yr}^{-1}$ are approximately $60 \%$ lower than those in $\mathrm{CN}_{-} \mathrm{a}\left(158 \mathrm{Tg} \mathrm{CH}_{4} \mathrm{yr}^{-1}\right)$; (3) high-latitude $\left(>50^{\circ} \mathrm{N}\right)$ wetland emissions in BGC are $97 \mathrm{Tg} \mathrm{CH}_{4} \mathrm{yr}^{-1}$ while $\mathrm{CN} \_$a only produces $12 \mathrm{Tg} \mathrm{CH}_{4} \mathrm{yr}^{-1}$. Such large differences are probably largely due to the shift of carbon from the tropics to the high latitudes as a result of the modifications from CN_a to BGC (see Sect. 3.2.3) (Koven 


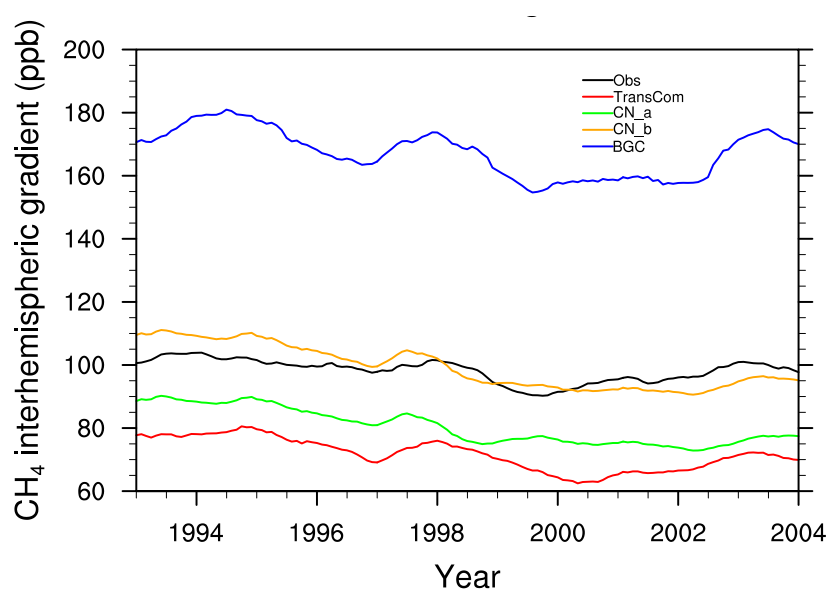

Figure 10. The interhemispheric gradients $(\mathrm{N}-\mathrm{S})$ in atmospheric $\mathrm{CH}_{4}$ concentration. The $\mathrm{N}-\mathrm{S}$ gradients are calculated as the difference in atmospheric $\mathrm{CH}_{4}$ concentration in Northern and Southern hemispheres at these stations listed in Table 1. The observational $\mathrm{CH}_{4}$ concentration data set at these stations is from the World Data Centre for Greenhouse Gases (WDCGG) at http://ds.data.jma.go.jp/ gmd/wdcgg/.

et al., 2013). BGC and CN_a produce similar methane emissions in the mid-latitudes $\left(20-50^{\circ} \mathrm{N}\right)$.

The latitudinal distribution of the methane emissions in CN_a suggests the largest seasonal variation occurs at approximately $20-30^{\circ} \mathrm{N}$, followed by the latitudinal band 50 $60^{\circ} \mathrm{N}$ (Fig. 7a). High latitudes $\left(>65^{\circ} \mathrm{N}\right.$ ) have no clear seasonal cycles due to the low methane fluxes that CN_a produces in the high latitudes (Meng et al., 2012). There is a very dampened seasonal variation of $\mathrm{CH}_{4}$ emissions in tropical wetlands $\left(10^{\circ} \mathrm{S}\right.$ to $\left.10^{\circ} \mathrm{N}\right)$, although tropical wetlands are the largest contribution to total wetland emissions. The seasonal cycle in the different latitudinal bands is consistent with that identified in Spahni et al. (2011) (see their Fig. 4a).

The latitudinal distribution of methane emissions shows a strong seasonal variation at high latitudes in the BGC simulation. As clearly shown in Fig. 7b, peak methane emissions (> $200 \mathrm{mg} \mathrm{CH}_{4} \mathrm{~m}^{-2} \mathrm{~d}^{-1}$ ) occur in summer seasons and low methane emissions $\left(\sim 10 \mathrm{mg} \mathrm{CH}_{4} \mathrm{~m}^{-2} \mathrm{~d}^{-1}\right)$ are present in winter. The maximum emissions occur at approximately $60^{\circ} \mathrm{N}$ as distinct from the $\mathrm{CN} \_$a simulations.

The peak emissions in BGC from 1993 to 2004 occur in 1998 followed by 2002, 1994, and 2003. The four lowest emission years are 1999, 2000, 2001, and 1996. As shown in Fig. 6b, the increase in methane emissions from the four lowest to highest years is primarily on the equator, in the Southern Hemisphere (around $30^{\circ} \mathrm{S}$ ) and in the high latitudes (50$70^{\circ} \mathrm{N}$ ). This is distinct from the CN_a simulations, where the largest change predominantly occurs in the tropics (Fig. 6a).

\subsubsection{Sources of the differences in CLM4.0- and CLM4.5-estimated methane emissions}

The large difference in spatial distribution of methane emissions between CN_a (CLM4.0) and BGC (CLM4.5) experiment is due to the change in soil biogeochemistry within the soil $\mathrm{C}$ and $\mathrm{N}$ models from CLM4.0 to CLM4.5. Koven et al. (2013) conduct a detailed analysis of the effect of such changes on C dynamics in the CLM model. Here, we briefly describe the changes that most affect high-latitude and tropical $\mathrm{C}$ dynamics, where the differences are the largest. The carbon cycle is linked to the nitrogen $(\mathrm{N})$ cycle because $\mathrm{N}$ availability in soils will affect vegetation growth. In CLM4.0, available mineral $\mathrm{N}$ experiences a first-order decay with a time constant of 2 days that is not subject to environmental limitations. At high latitudes, the long winters allow most mineral $\mathrm{N}$ to decay and only a limited amount of $\mathrm{N}$ is available for vegetative growth during the short growing season. Therefore, in the high latitudes, CLM4.0 simulates low productivity and low heterotrophic respiration (HR) available for methane production (in CLM4Me, methane production is a function of heterotrophic respiration, see methane production equation in Sect. 2.1). In CLM4.5, an introduction of the dependence of $\mathrm{N}$ losses on temperature and soil moisture and seasonality of $\mathrm{N}$ fixation reduce the unrealistic $\mathrm{N}$ limitation in CLM4.0. Thus, CLM4.5 allows for more $\mathrm{N}$ to be used for vegetation growth and produces higher soil carbon, higher heterotrophic respiration (HR), and thus higher methane fluxes. As shown in Appendix Fig. A1, HR in CLM4.5 is much higher than that in CLM4.0, particularly in the Northern Hemisphere summer season when most $\mathrm{CH}_{4}$ is produced. Please note that annual $\mathrm{CH}_{4}$ emissions from northern latitudes are not affected by winter time $\mathrm{HR}$ because $\mathrm{CH}_{4}$ is not produced in winter seasons due to below-freezing temperatures.

Other changes that affect tropical $\mathrm{C}$ dynamics include calculation of decomposition rates at each model level in CLM4.5 instead of limiting the calculation to top $30 \mathrm{~cm}$ in CLM4.0, based on moisture and temperatures and inclusion of oxygen availability as a limitation factor as well as vertical mixing of soil organic matter. These changes primarily reduce terrestrial gross primary productivity (GPP) in tropical forests as a result of reduction in photosynthesis. The change in nitrogen cycle described above also has an effect on tropical $\mathrm{C}$ dynamics by removing $\mathrm{N}$ limitation, which makes the biosphere more sensitive to the increased temperature and $\mathrm{CO}_{2}$ concentration and leads to a large net uptake of carbon. The overall effect of the changes in CLM4.5 in the tropics is to reduce heterotrophic respiration (HR), resulting in a decrease in methane production. Fig. A1 shows that the HR is much lower in CLM4.5 compared to CLM4.0 in the tropics. Comparisons of net primary production (NPP) and soil $\mathrm{C}$ between CLM4.5 and CLM4.0 are presented in Figs. B1 and C1. 

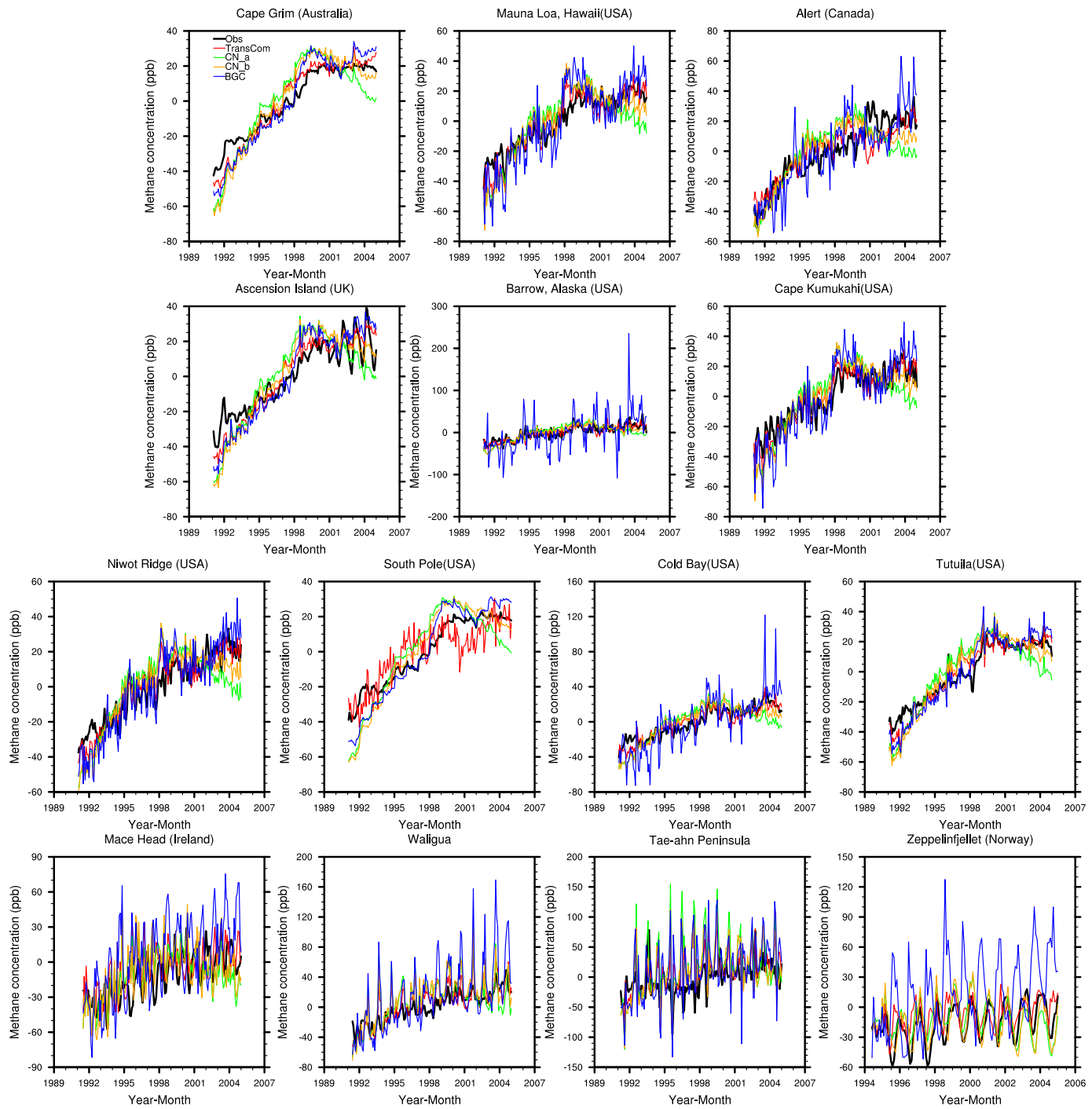

Figure 11. The comparison of model-simulated atmospheric $\mathrm{CH}_{4}$ concentration at the closest grid box vs. observations. The climatological monthly mean is removed to focus on interannual variability in atmospheric $\mathrm{CH}_{4}$ concentration at these stations. Model simulations are obtained from TransCom, CN_a, CN_b, and BGC experiments. The observational $\mathrm{CH}_{4}$ concentration data set at these stations is from the World Data Centre for Greenhouse Gases (WDCGG) at http://ds.data.jma.go.jp/gmd/wdcgg/.

\subsection{Contribution of individual sources to seasonal and interannual variability in atmospheric $\mathrm{CH}_{4}$}

In order to determine the relative contribution of each source to total atmospheric $\mathrm{CH}_{4}$ variability as simulated in CAMchem, we calculate the seasonal and interannual root mean square (RMS) variability for the total $\mathrm{CH}_{4}$ concentration and the relative contribution of the anthropogenic source, rice paddies, and wetlands to the overall RMS (Figs. 8 and 9). These three sources have the largest contribution to the annual RMS due to their large magnitudes.

\subsubsection{Seasonal and interannual variability in $\mathbf{C N} \_a$ methane emissions}

Seasonal variability of atmospheric methane concentrations is high in the tropics and Southern Hemisphere and low in the northern high latitudes in the CN_a simulations (Fig. 8). The low seasonal variability in the northern high latitudes is consistent with the relatively low magnitude of northern high-latitude methane fluxes in the $\mathrm{CN}_{-}$a simulations, plus the fact that the highest emissions occur during the summer, when the vertical mixing is highest.

Interannual variability (IAV) in RMS is relatively homogeneous across the globe with slightly higher IAV in the Southern Hemisphere (Fig. 8). Overall, the IAV RMS of 


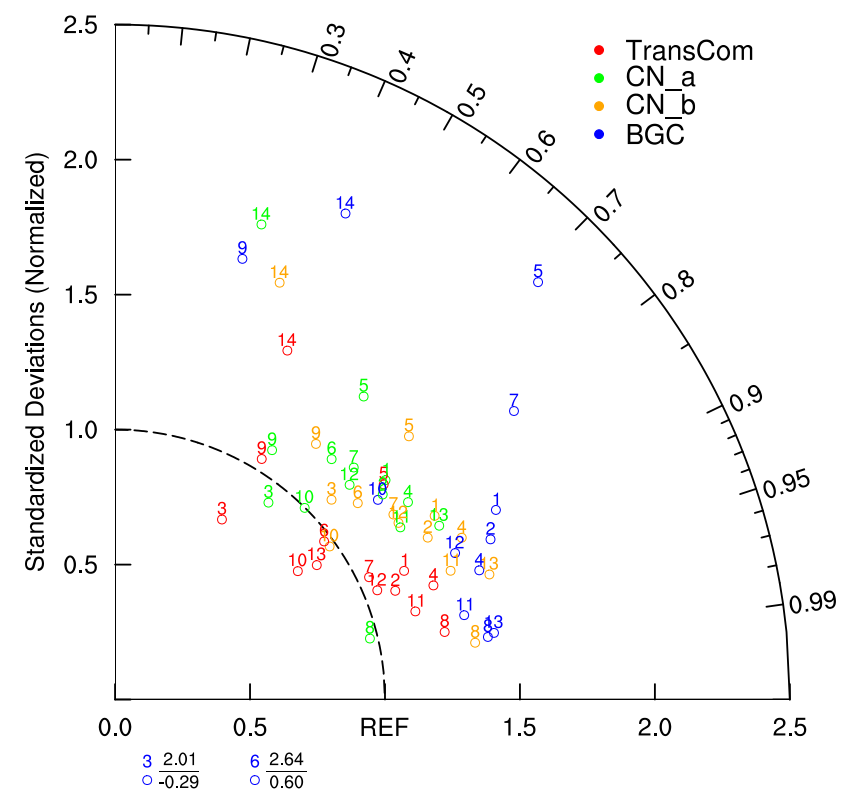

Figure 12. Taylor diagrams comparing the model interannual variability to methane observations at 14 stations. In this Taylor diagram, the angle from the $x$ axis is the correlation coefficient between model and observed time series of atmospheric $\mathrm{CH}_{4}$ concentration. The value on the radial axis is the standard deviation ratio: $\sigma_{\text {model }} / \sigma_{\text {obs }}$. It represents the match between the amplitude of the model and observed interannual variability. Please refer to Table 2 for the stations associated with each number.

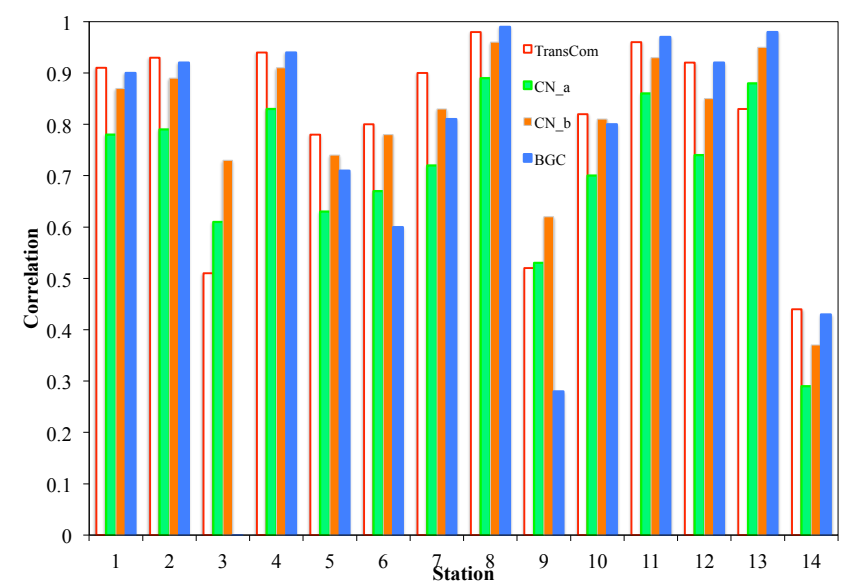

Figure 13. Comparison of correlations between TransCom, CN_a, CN_b, BGC, and observations (same as in Fig. 12). The station numbers correspond to those in Table 2.

atmospheric methane is generally larger than the seasonal RMS. Anthropogenic sources and wetlands are the dominant contributors to the seasonal RMS variability in the Northern Hemisphere (Fig. 8), while wetlands are the only dominant contributor to the IAV RMS variability. This is in agreement with Bousquet et al. (2006), who reported that wetland emissions dominate the interannual variability of methane sources. Rice paddies play a more important role in seasonal RMS variability than in interannual RMS variability over Asia and North America. This is consistent with the largest seasonal variations in rice paddy emissions occur over Asia and North America (Meng et al., 2012). Similar results are also found in CN_b simulations.

\subsubsection{Seasonal and interannual variability in BGC methane emissions}

Compared to CN_a, the BGC methane emissions show higher seasonal and interannual variability, particularly at high latitudes (Fig. 9). For instance, Alaska and Siberia have the highest variability. For both the seasonal and interannual variations, wetlands dominate the variability, followed by anthropogenic sources. Rice paddies only play a role in the tropics $\left(0-30^{\circ} \mathrm{N}\right)$. Both wetlands and anthropogenic methane emissions in BGC contribute a higher percentage to the interannual variations than in the $\mathrm{CN} \_$a simulations.

\subsection{Interhemispheric gradients in atmospheric $\mathrm{CH}_{4}$ concentrations}

The latitudinal gradient from TransCom, CN_a, CN_b, BGC, and observations is shown in Fig. 10. The latitudinal gradient is defined as the difference in averaged $\mathrm{CH}_{4}$ concentration between the Northern and Southern hemispheres $(\mathrm{N}-\mathrm{S}$ gradients); stations listed in Table 2 . The $\mathrm{N}-\mathrm{S}$ gradients produced in all four simulations are highly correlated with observations for the period of 1993-2004 (Fig. 10). The correlations $(r)$ are $0.83,0.72,0.76$, and 0.91 (all four correlations are significant at $95 \%$ confidence level) for TransCom, CN_a, CN_b, and BGC, respectively. It is also clearly shown in Fig. 10 that the TransCom and CN_a simulations underestimate the $\mathrm{N}-\mathrm{S}$ hemisphere gradients. The underestimation of $\mathrm{N}-\mathrm{S}$ gradients in $\mathrm{CN} \_$a might be due to the high tropical wetland emissions in this case as the high tropical emissions are likely to increase the $\mathrm{CH}_{4}$ concentration in the Southern Hemisphere. The BGC simulation significantly overestimates the N-S hemisphere gradients, by about $70 \%$, consistent with the large high-latitude methane emissions in this simulation and the low tropical emissions. The CN_b simulation, with the same anthropogenic emissions as TransCom, but decreased wetland methane emissions, compared with $\mathrm{CN} \_\mathrm{a}$, best reproduces the observed $\mathrm{N}-\mathrm{S}$ gradient during the period of 1993-2004. The N-S gradients decrease between 1993 and 2004 in TransCom, CN_a, and CN_b experiments, although there is only slight decrease in the measurements (Fig. 10). Dlugokencky et al. (2011) calculate the inter-polar difference (IPD) (difference between the northern $\left(53-90^{\circ} \mathrm{N}\right)$ and southern $\left(53-90^{\circ} \mathrm{S}\right)$ annual mean $\mathrm{CH}_{4}$ concentration) from the observations and find a slight decrease in IPD from 1993 to 2010. 


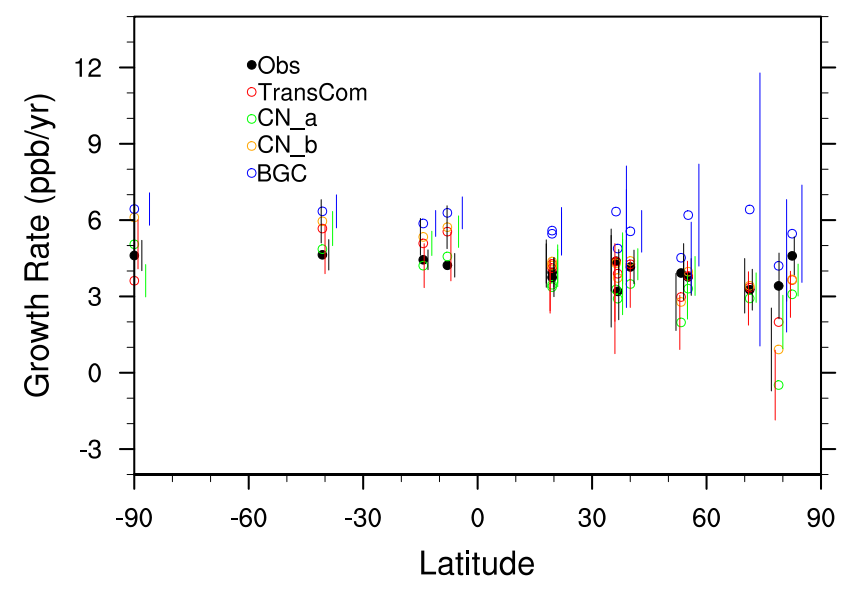

Figure 14. Atmospheric $\mathrm{CH}_{4}$ growth rate as a function of latitude in observations, TransCom, CN_a, CN_b, and BGC simulations. $90 \%$ confidence intervals are also shown.

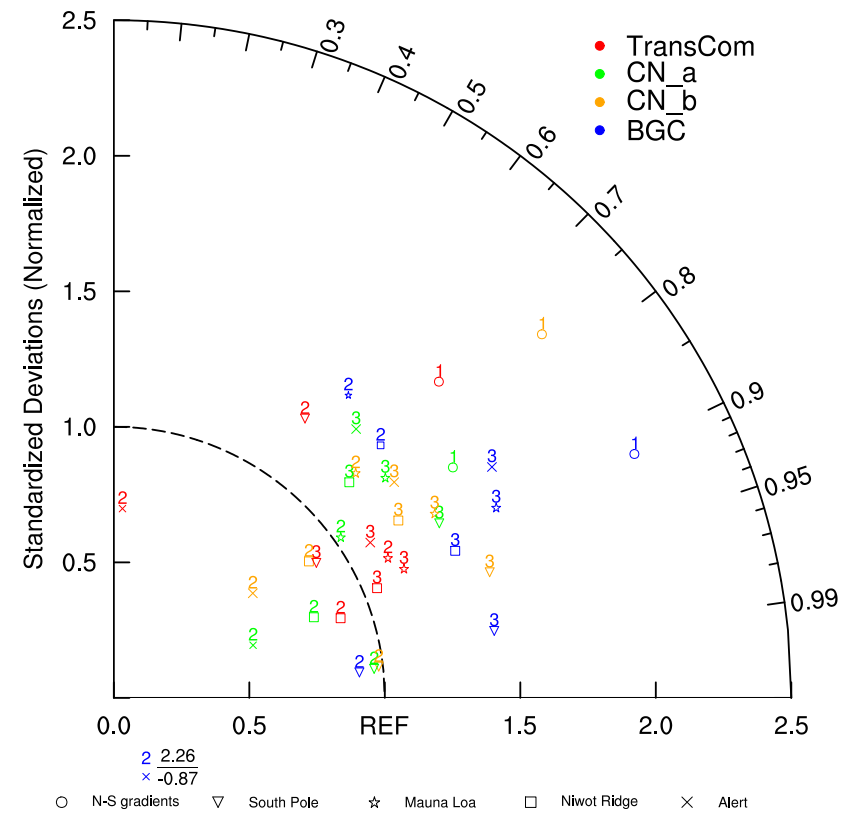

Figure 15. Taylor diagram comparing model N-S gradients (no. 1), annual growth rates (no. 2), and interannual variability (no. 3) with observations for the South Pole, Mauna Loa, Niwot Ridge, and Alert (Canada) stations, respectively for the four simulations. The four stations are selected to represent the South Pole, tropics, mid-latitudes, and high latitudes. The annual growth rate is calculated as the difference between the mean methane concentrations of the current year and the previous year. The $\mathrm{N}-\mathrm{S}$ gradients are from Fig. 10.

\subsection{Evaluation of model interannual variability}

Model simulation of the IAV of atmospheric $\mathrm{CH}_{4}$ concentrations is evaluated against site observations over 14 stations (Table 1) around the world. The climatological seasonal cycle is removed in order to focus on the IAV. CN_a simulates the trend in methane from 1993 to approximately 2001 at all of the stations, but tends to underestimate observations during the later period (2001-2004) (Fig. 11). Such an underestimation might be due to the large decrease in $\mathrm{CN} \_$a simulated wetland emissions (Fig. 5). The CN_b simulation with decreased wetland emissions (CN_b in Fig. 11) shows increased atmospheric methane concentrations during the later period (2001-2004), allowing for a better match between observations and model simulations. In the BGC simulation, model-simulated atmospheric concentrations are relatively flat from 1998 to 2004, which match the observations well (Fig. 11). In the TransCom experiment, simulated $\mathrm{CH}_{4}$ concentration anomalies are generally in good agreement with observations at all of the stations.

The Taylor diagram of model-observation comparisons of interannual variability show that TransCom performed the best among the three cases while CN_b and BGC simulations performed slightly better than $\mathrm{CN} \_$a due to a better correlation with the measurements (Fig. 12). The performance of BGC simulations is comparable to (or slightly better than) TransCom in terms of the correlation (Fig. 13) although the model tends to overpredict the amplitude of the interannual variability. Decreasing wetland emissions (CN_b) allows for a better match between model simulations and observations. This suggests that CN_a simulations might overestimate wetland emissions, which agrees with the findings in Kirschke et al. (2013).

\subsection{Methane growth rate}

The growth rate refers to the average increase in atmospheric $\mathrm{CH}_{4}$ concentration per year. We calculate the growth rate at each station from the observations and for each simulation. The observed average growth rate ranges from 3.2 to $4.6 \mathrm{ppbyr}^{-1}$ with an average of $4.0 \mathrm{ppb} \mathrm{yr}^{-1}$ (Fig. 14, Table 3). The average growth rate in TransCom, CN_a, CN_b, and BGC experiments is $4.2,3.29,4.05$, and $5.68 \mathrm{ppb} \mathrm{yr}^{-1}$, respectively (Table 3 ). The growth rate in TransCom, CN_a, $\mathrm{CN} \_$b, and BGC simulations has a large range (from -0.48 to $6.44 \mathrm{ppb} \mathrm{yr}^{-1}$ ) at all stations analyzed. As can be seen from Fig. 14, both CN_a and CN_b tend to underestimate the observed growth rate in the Northern Hemisphere, but overestimate it in the Southern Hemisphere (Fig. 14) except for the South Pole station. BGC tends to overestimate the growth rate in the Northern Hemisphere, particularly in the high latitudes (Fig. 14). TransCom gives better agreement with the measured growth rates in the Southern Hemisphere than in the Northern Hemisphere. The largest difference in the growth rate between the three cases and the observations occur at the Zeppelinfjellet (zep, Norway) where the average growth rate in TransCom, CN_a, CN_b, BGC, and observations was $-0.92,-0.48,1.99,4.2$, and $3.4 \mathrm{ppb} \mathrm{yr}^{-1}$, respectively (Table 3). The largest difference between BGC and observations is at Barrow, where the growth rate in BGC experiment was approximately 2 times of that in observations. 
Overall, CN_a and CN_b underestimate the station growth rate at high latitudes while $\mathrm{BGC}$ overestimates it.

In addition, a summary of the comparison of model $\mathrm{N}-$ $\mathrm{S}$ gradients, annual growth rates, and interannual variability with observations is presented in Fig. 15. Four stations are specifically selected to represent the South Pole, tropical regions, mid-latitudes, and high northern latitudes. Root mean square errors and biases for the four simulations at these four stations are listed in Table 4. As seen in Fig. 15, and discussed above, no one model simulation best matches all the observational metrics.

\subsection{Comparison of interannual variability between this study and others}

We also compare the interannual variability in $\mathrm{CH}_{4}$ emission anomalies in the simulations analyzed here with those given in Spahni et al. (2011), in an updated long-term atmospheric synthesis inversion from Bousquet et al. (2006) and from Ringeval et al. (2010). (Fig. 16). As discussed above, the CN_a emissions reach their maximum in 1994 and decrease thereafter from 1994 to 2004 (Fig. 16). The BGC emissions have the highest emissions in 1998, the lowest emissions in 1999, and increased emissions from 1999 to 2004. The TransCom emissions increase from 1993 to 1998 and slightly decrease thereafter. The wetland emissions in Ringeval et al. (2010) decrease from 1993 to 2000. The Ringeval et al. (2010) averaged annual wetland methane emissions are $\sim 215 \mathrm{Tg} \mathrm{yr}^{-1}$, similar to the CN_a wetland emissions. However, the atmospheric synthesis inversions of global wetland emissions (update of Bousquet et al., 2006 (constant OH)) increase from 1990 to 2000 followed by a decrease from 2000 to 2005. Thus, there seems to be little agreement in the interannual variability of the wetland methane emissions between these various simulations.

We further compare our model-derived wetland emissions with those from the Wetland and Wetland $\mathrm{CH}_{4}$ Intercomparison of Models Project (WETCHIMP) (Melton et al., 2013; Wania et al., 2013). We conduct two different comparisons: one includes all models with their different parameterizations of wetland extent while the other focuses on models that are driven by satellite-derived inundation data sets (see Table 1, Melton et al., 2013).

Each model analyzed in Melton et al. (2013) uses a different wetland parameterization to estimate their wetland extent (see Table 1 in Melton et al. (2013) for details). Therefore, it is not surprising to see the large variation in wetland extent among these models from 1993 to 2004 (Fig. 17). Among the models analyzed in Melton et al. (2013), only the LPJ-WSL model uses prescribed monthly inundation data sets, similar to our simulations (Fig. 17). DLEM_norice prescribes maximum extent at each grid cell from satellite-derived inundation data sets but with simulated intra-annual dynamics. All simulations making use of the satellite measurements (this study, LPJ-WSL, BGC, and DLEM_norice) show a decrease

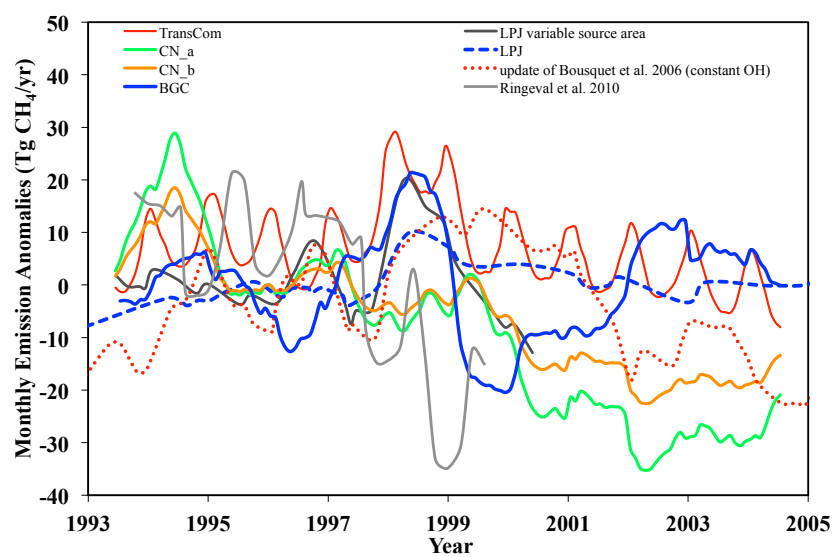

Figure 16. Comparison of the interannual variability in wetland $\mathrm{CH}_{4}$ emissions used in this study and in others. A centered 12month running mean filter has been applied to smooth monthly output. Data for "LPJ variable source area", "LPJ", and "update of Bousquet et al. (2006) (constant OH)" are obtained from Spahni et al. (2011). "LPJ variable source area" indicates emissions anomalies for 1993-2000 calculated by using the observed monthly inundated area (Prigent et al., 2007). "LPJ" indicates global $\mathrm{CH}_{4}$ emission anomalies simulated by LPJ (natural ecosystem and rice agriculture) for scenario SC2 listed on Spahni et al. (2011). "update of Bousquet et al., 2006 (constant $\mathrm{OH}$ )" refers to global wetland emission anomalies derived from long-term atmospheric synthesis inversion updated from Bousquet et al. (2006). TransCom refers to emission anomalies derived from the combined wetland and rice paddy emissions. Methane emissions in Ringeval et al. (2010) are estimated using the ORCHIDEE global vegetation model with a process-based wetland $\mathrm{CH}_{4}$ emission model. The wetland area is prescribed to the observed monthly inundated area (Prigent et al., 2007) in Ringeval et al. (2010). The mean anomalies over 19932000 are adjusted to zero for the all data plotted on this graph.

Table 3. Comparison of the mean growth rate $\left(\mathrm{ppbyr}^{-1}\right)$ of atmospheric methane concentration in each simulation with observations.

\begin{tabular}{lrrrrrr}
\hline Station & Lat & Obs & TransCom & CN_a & CN_b & BGC \\
\hline spo & -89.98 & 4.61 & 6.11 & 5.05 & 3.62 & 6.44 \\
cgo & -40.68 & 4.64 & 5.96 & 4.86 & 5.67 & 6.35 \\
smo & -14.24 & 4.44 & 5.34 & 4.21 & 5.09 & 5.87 \\
asc & -7.92 & 4.23 & 5.72 & 4.57 & 5.55 & 6.29 \\
kum & 19.52 & 3.75 & 4.21 & 3.37 & 4.12 & 5.46 \\
mlo & 19.53 & 3.95 & 4.37 & 3.46 & 4.28 & 5.59 \\
wlg & 36.28 & 4.39 & 4.3 & 3.27 & 4.37 & 6.34 \\
tap & 36.72 & 3.2 & 3.72 & 2.92 & 3.89 & 4.88 \\
nwr & 40.05 & 4.16 & 4.4 & 3.49 & 4.27 & 5.56 \\
mhd & 53.33 & 3.92 & 2.78 & 1.98 & 2.98 & 4.52 \\
cba & 55.20 & 3.77 & 3.97 & 3.31 & 3.81 & 6.2 \\
brw & 71.32 & 3.27 & 3.42 & 2.92 & 3.35 & 6.42 \\
zep & 78.90 & 3.42 & 0.92 & -0.48 & 1.99 & 4.2 \\
alt & 82.45 & 4.6 & 3.67 & 3.08 & 3.65 & 5.47 \\
Average & & 4.03 & 4.21 & 3.29 & 4.05 & 5.69 \\
\hline
\end{tabular}


Table 4. Model performance statistics including the root mean square error (RMSE) and bias ( $\mathrm{ppb} \mathrm{yr}^{-1}$ ). Bias is calculated as the absolute deviation of the mean between model simulations and observations.

\begin{tabular}{|c|c|c|c|c|c|c|c|c|c|}
\hline \multirow[b]{2}{*}{ RMSE } & \multirow[t]{2}{*}{$\mathrm{N}-\mathrm{S}$ gradients } & \multicolumn{4}{|c|}{ Growth rate } & \multicolumn{4}{|c|}{ Interannual variability } \\
\hline & & South Pole & Mauna Loa & Niwot Ridge & Alert & South Pole & Mauna Loa & Niwot Ridge & Alert \\
\hline TransCom & 25.92 & 5.41 & 3.55 & 2.44 & 11.65 & 10.47 & 8.28 & 7.35 & 8.69 \\
\hline CN_a & 17.57 & 0.57 & 4.22 & 2.88 & 5.13 & 12.65 & 13.96 & 14.59 & 15.06 \\
\hline CN_b & 5.39 & 0.59 & 5.74 & 4.19 & 6.06 & 11.32 & 12.1 & 11.88 & 12.03 \\
\hline BGC & 69.62 & 0.67 & 7.78 & 6.81 & 30.88 & 8.88 & 13.97 & 10.89 & 14.18 \\
\hline Bias & & South Pole & Mauna Loa & Niwot Ridge & Alert & South Pole & Mauna Loa & Niwot Ridge & Alert \\
\hline TransCom & 0.26 & 0.58 & 0.3 & 0.22 & -1.69 & 0.08 & 0.01 & 0.02 & 0.01 \\
\hline CN_a & 0.17 & 0.03 & 0.05 & 0.29 & -1.05 & 0.02 & 0.02 & 0.03 & 0.04 \\
\hline CN_b & 0.02 & 0.07 & 0.06 & 0.34 & -0.72 & 0.03 & 0.02 & 0.02 & 0.03 \\
\hline BGC & 0.71 & 0.06 & 1.36 & 1.29 & -3.13 & 0.01 & 0.02 & 0.02 & 0.04 \\
\hline
\end{tabular}

in wetland extent from 1993 to 2004. The wetland extent anomalies in DLEM_norice simulations differ as the intraannual dynamics are simulated (Fig. 17).

The models that do not use a prescribed satellite-derived inundation data set do not simulate notable decreases in wetland extent during the period of 1993-2004 (Fig. 17). This is not in agreement with the satellite-derived inundation data set: Papa et al. (2010) find $\sim 5.7 \%$ decrease in mean annual maximum inundation from 1993 to 2004 with a maximum decrease in the tropics (see Appendix). In fact, all models (excluding LPJ-WSL, DLEM_norice, and this study) show large increases in wetland extent in 1998 compared to 1997, which is also documented in Melton et al. (2013).

Melton et al. (2013) demonstrate that the difference in wetland area used in different models might partially explain the discrepancy in model-estimated wetland emissions. As shown in Melton et al. (2013), model-derived methane emissions are strongly correlated with the wetland extent (with an average correlation of 0.90 on the global scale). All models that produce a peak methane emission in 1998 have a maximum wetland extent at the same time (Fig. 18). The difference in model-derived methane emissions can be attributed partially to the different wetland area used in each model, where the wetland extent is highly uncertain (Melton et al., 2013). However, it should be noted that there are several limitations associated with using wetland extent derived from satellite-derived inundation data sets. As suggested in Prigent et al. (2007), satellites might underestimate inundated areas due to their incapability to detect small water bodies. Furthermore, satellite data sets only include fully inundated areas and excluded unsaturated wet mineral soils, which might also be an important wetland methane source (Spahni et al., 2011).

The methane emission anomalies in DLEM_norice and LPJ_WSL (the simulations in Melton et al. (2013) using satellite-derived wetland extent) show similar temporal variations, as do the methane anomalies in $\mathrm{CN}_{-} \mathrm{a}$ and
CN_b simulations (Fig. 18). Emissions estimated in CN_a, CN_b, DLEM_norice, and LPJ_WSL peak in 1993-1994 and showed a decrease afterwards. Such a decreasing trend is consistent with the decrease in wetland extent used in these models (Fig. 17). The CN_a and CN_b simulations show a large increase in emissions from 1993 to 1994 , but do not simulate large increases in methane emissions from 2001 to 2002 even though wetland extent increases during this period. It should be noted that the BGC simulation uses the same wetland extent as $\mathrm{CN} \_\mathrm{a}$ and $\mathrm{CN} \_\mathrm{b}$ but does not give the same large decrease in the emissions during the period of 1993-2004. In fact, the BGC model gives decreasing emissions from 1993 to 1994 but increasing methane emissions from 2001 to 2002. The BGC model also shows that the highest emission occurs in 1998 and the lowest in 1999 during the period of 1993-2004.

Both the large increase in the methane emissions from 1993 to 1994 in CN_a and CN_b and the small increase from 2001 to 2002 are likely due to the changes in heterotrophic respiration (HR) in CN_a and CN_b simulations (Fig. 19). Please note that the methane production in the models is a function of HR (see the methane production equation in Sect. 2.1). Please see Meng et al. (2012) and Riley et al. (2011) for a detailed description of the processes of methane production, oxidation, and transport). HR increases dramatically in CN_a from 1993 to 1994 (Fig. 19) driving higher methane emissions, whereas the decrease in HR from 2001 to 2002 decreases wetland methane production, which might offset the increase in methane emissions from wetland extent. The HR in the BGC simulation is rather different, consistent with the different behavior between CN_a and CN_b and the BGC simulations. Zhao et al. (2005) estimate the net primary production (NPP) from satellites and find that NPP in 2001 is higher than those in 2002 and 2003. Please note that NPP is related to HR. The correlation of global wetland emissions with HR and wetland extent is 0.81 and 0.94 , respectively, in CN_a simulations. In BGC simulations, sim- 


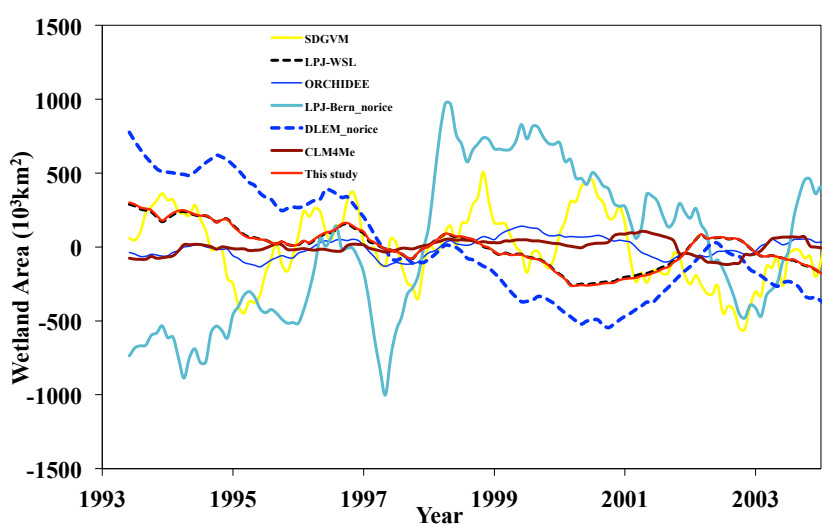

Figure 17. 12-month smoothed average of the anomalies in wetland areal extent used in the models that participate in WETCHIMP project (Melton et al., 2013; Wania et al., 2013) and in this study (satellite-derived inundated area obtained from Prigent et al. (2007) and Papa et al., 2010). LPJ-Bern_norice and DLEM_norice are LPJ-Bern and DLEM models that do not include rice paddy simulations, respectively. These notifications indicate WETCHIMP project also produce simulations with rice and only no rice simulations are included in this comparison study. In this figure, the long-term mean (1993-2004) is removed from each data set.

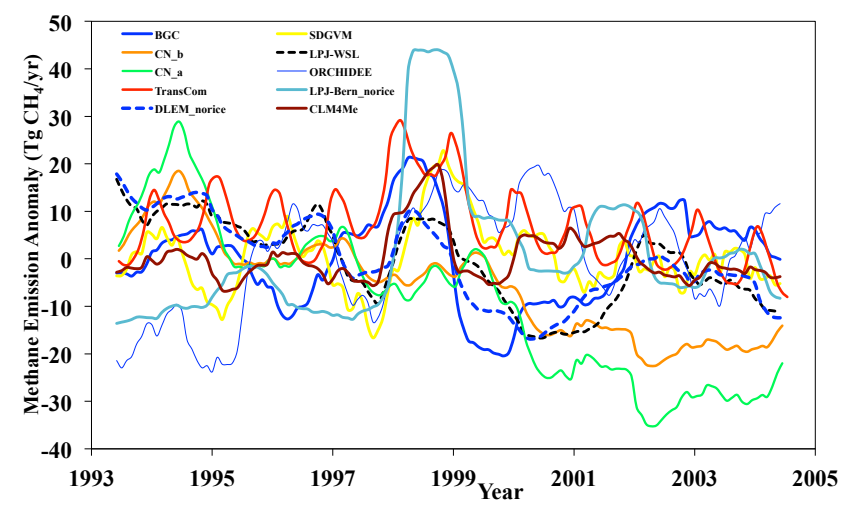

Figure 18. Similar to Fig. 16, but showing the models that participate in WETCHIMP (Melton et al., 2013; Wania et al., 2013). Each model uses a different wetland extent to estimate methane emissions (see Table 1 in Melton et al. (2013) for wetland determination scheme in each model). LPJ-WSL prescribes the wetland area from a monthly inundation data set (Prigent et al., 2007, Papa et al., 2010). DLEM_norice prescribes the maximum wetland area from the inundation data set with simulated intra-annual dynamics. Sheffield Dynamic Global Vegetation Model (SDVGM) uses the internal hydrological model to determine wetland locations. All other models parameterize wetland areas based on an inundation data set or a land cover data set, which produce different interannual and intra-annual variability in wetland areas. Please also refer to Melton et al. (2013) for a detailed description of each model (SDVGM, LPJ-WSL, ORCHIDEE, LPJ-Bern_norice, DLEM_norice, CLM4Me).

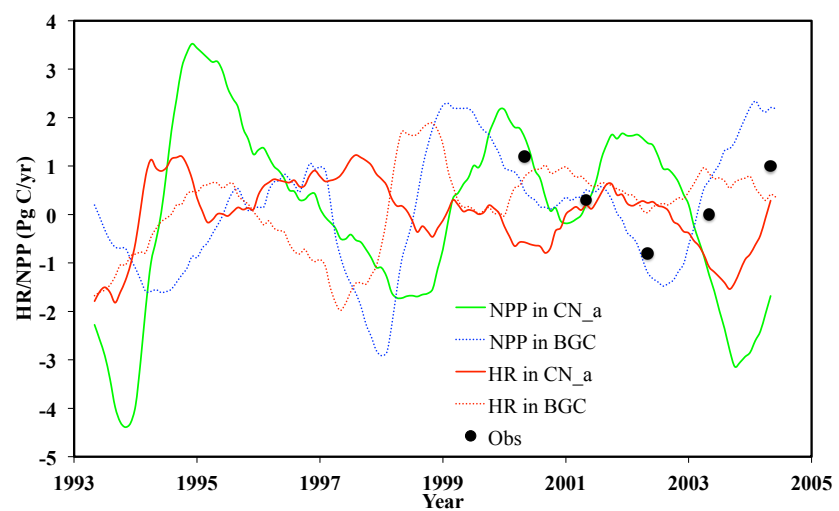

Figure 19. Temporal variation of the anomalies in globally averaged heterotrophic respiration (HR) and net primary production (NPP) in CN_a and BGC experiments. Blue dots indicate globally averaged NPP anomalies from satellites obtained from Zhao and Running (2010). A 12-month smoothing is applied to monthly anomalies in HR and NPP.

ulated global wetland emissions are also highly correlated with HR (0.89) and with wetland extent (0.81). Such high correlations suggest that both $\mathrm{HR}$ and wetland extent are dominate drivers of wetland methane emissions in the $\mathrm{CN}_{-} \mathrm{a}$ and BGC models. Thus, although the BGC experiment uses the same satellite-derived inundated area in CN_a, it does not produce a decreasing trend in methane emissions during the period, probably due to its different trend in HR estimated in BGC as compared with that in CN_a (Fig. 19).

\section{Conclusions}

In this study, we evaluate the temporal and spatial patterns in wetland methane emissions simulated in CLM4Me' from two different parameterizations of soil carbon-nitrogen dynamics as included in CLM4.0 (CN_a and CN_b) and CLM4.5 (BGC). The subsequent methane distributions are simulated in CAM-chem using meteorological drivers consistent with those used to drive the $\mathrm{CN}$ and BGC models. Our goals for this study are (i) to evaluate the wetland methane fluxes simulated in the two versions of CLM so as determine the sensitivity of methane emissions to the underlying carbon model; (ii) to compare the simulated atmospheric methane concentrations to atmospheric measurements, including latitudinal gradients and interannual variability, so as to determine the extent to which the atmospheric observations constrain the emissions; (iii) to understand the drivers of seasonal and interannual variability in atmospheric methane fluxes.

Even though they are driven by identical meteorological forcing and satellite-derived wetland area, there are significant differences in the interannual and spatial variations between the $\mathrm{CN}$ and BGC wetland methane emissions as derived by CLM4Me'. This demonstrates the critical sensitiv- 
ity in the simulation of wetland emissions to the underlying model. Compared to the $\mathrm{CN}$ a simulations, the BGC simulations produce large emissions $\left(\sim 97 \mathrm{Tg} \mathrm{yr}^{-1}\right.$ on average $)$ in the northern high latitudes $\left(50-90^{\circ} \mathrm{N}\right)$ with very strong seasonal variations (from no emissions in $\mathrm{NH}$ winter to more than $300 \mathrm{Tg} \mathrm{yr}^{-1}$ in $\mathrm{NH}$ summer) and relatively small wetland emissions (only $\sim 30 \%$ of global emissions) in the tropical region. On the other hand, the $\mathrm{CN}$ _a simulation has very large tropical emissions ( $\sim 70 \%$ of global wetland emissions) so that changes in the tropics dominate global emissions.

The large difference in their high-latitude emissions can be ascribed to the different simulation of nitrogen dynamics in the $\mathrm{CN}$ and BGC simulations. In CLM4.0, available mineral $\mathrm{N}$ experiences a first-order decay with a time constant of 2 days, which is not subject to environmental limitations, while in the BGC simulation the an introduction of the dependence of $\mathrm{N}$ losses on temperature and soil moisture and the seasonality of $\mathrm{N}$ fixation reduce the unrealistic $\mathrm{N}$ loss in CLM4.0. The larger nitrogen availability in the BGC model at high latitudes allows greater carbon pools to develop, thus increasing the heterotrophic respiration at high latitudes. The large difference in tropical wetland emissions between the BGC and CN_a experiments is possibly due to the changes in decomposition rates, carbon vertical mixing, and the release of nitrogen limitation from the $\mathrm{CN}$ _a to the BGC model (Koven et al., 2013). Overall, these changes reduce NPP and HR in the tropics, which directly impacts the methane fluxes.

Both the $\mathrm{CN}$ and BGC simulations also differ in the relative magnitude of seasonal vs. interannual variability (IAV) of atmospheric methane concentrations for the period of 1993-2004. IAV is relatively higher (average total RMS is approximately $20 \mathrm{ppb}$ ) than the seasonal variability (approximately $10 \mathrm{ppb}$ ) across the globe in CN_a (Fig. 8), while in BGC, IAV is much higher $(\sim 25 \mathrm{ppb})$ than the seasonal variability $(\sim 10 \mathrm{ppb})$ except for the northern latitudes $\left(>50^{\circ} \mathrm{N}\right)$ (Fig. 9). Anthropogenic sources and wetlands contribute significantly to seasonal variations of atmospheric methane concentrations in CN_a and BGC. Wetland emissions dominate global interannual variability when CAM-chem is forced with either the CN_a or BGC methane emissions, in agreement with findings in Bousquet et al. (2006).

There are also substantial differences in the interannual variability between the two model versions. CN_a wetland emissions suggest a decreasing trend from 1994 to 2004, which is similar to those estimates from Ringeval et al. (2010) and DLEM_norice and LPJ-WSL models (Melton et al., 2013; Wania et al., 2013). On the other hand, CLM4Me' methane emissions driven by CLM4.5 (the BGC simulation) are highest in 1999 and do not show significant decrease during the period. The updated estimate from Bousquet et al. (2006) gives increasing emissions from 1991 to 2000 and a decrease after 2000. A few participating wetland emission models in the WETCHIMP project also predict peak methane emissions in the middle of the period (around 1998-1999).

The methane emissions in all simulations conducted here are input into CAM-chem so as to constrain the resulting atmospheric methane concentrations against atmospheric measurements. The meteorological fields driving atmospheric and land models are consistent. In particular, we compare the simulations against measured the interhemispheric gradient, interannual variability, and growth rate. Our results show that CN_b simulations (with reduced CN_a wetland emissions) are able to better produce observed atmospheric methane concentrations and the observed $\mathrm{N}-\mathrm{S}$ gradient in methane concentrations, suggesting that $\mathrm{CN}$ _a might overestimate the current wetland emissions. In the BGC experiment, modeled atmospheric interannual variability in concentrations has higher correlations with observations than the CN_a and CN_b simulations in the majority of stations (Fig. 13). In the TransCom experiment, the magnitude of the correlation between modeled atmospheric concentrations and observations is similar to that of the BGC experiment. We also find that CN_b experiments tend to underestimate the growth rate and $\mathrm{BGC}$ overestimates it at high latitudes. TransCom simulations have an overall better estimation of the growth rate at all stations than the other three simulations. In terms of the $\mathrm{N}-\mathrm{S}$ gradients, $\mathrm{CN}$ _b experiments have the closest match with observations among all experiments. BGC overestimated the N-S gradients by $\sim 70 \%$ while CN_a and TransCom underestimate it by $\sim 10$ and $\sim 20 \%$, respectively. Note that $\mathrm{BGC}$ predicts much higher methane emissions from the high latitudes $\left(>50^{\circ} \mathrm{N}\right)$ than $\mathrm{CN}$ a and CN_b experiments. These simulations generally suggest that the BGC high-latitude fluxes $\left(\sim 97 \mathrm{Tg} \mathrm{yr}^{-1}\right)$ are unlikely due to its overestimation of the $\mathrm{N}-\mathrm{S}$ gradients by $\sim 70 \%$. The high-latitude methane emissions should be somewhere in the broad range between those used in $\mathrm{CN} \_\mathrm{b}\left(\sim 7.7 \mathrm{Tg} \mathrm{yr}^{-1}\right)$ and BGC ( $\left.~ 97 \mathrm{Tg} \mathrm{yr}^{-1}\right)$. In general, however, no one model simulation best matches all the observational metrics. This study confirms that the large variation in methane emissions exists and wetland methane emissions play an important role in affecting atmospheric methane concentrations (Bousquet et al., 2006).

The comparison of the IAV demonstrates large disagreement between different estimates of the annual wetland emissions. Such a discrepancy in the variability produced in different models suggests that wetland extent plays an important role in controlling wetland emissions. We find large uncertainties exist in wetland extent and wetland methane emissions, in support of the conclusions of Melton et al. (2013). For instance, all models (excluding DLEM_norice and LPJWSL) that estimate a peak methane emission in 1998 also produce a peak wetland extent during the same period of 1993-2004. Such a decrease after 2003 is consistent with a decrease in the tropical inundated area, based on satellite observations. 
In addition to wetland extent, the model-simulated carbon pool also has a significant impact on methane emissions (Riley et al., 2011; Bloom et al., 2012). Both CN_a and BGC methane simulations are forced with the same satellitederived inundated fraction, they produce large differences in both spatial and temporal variations of methane emissions due to the fact that $\mathrm{CN} \_\mathrm{a}$ and $\mathrm{BGC}$ use different carbon cycle models. Although satellite-derived inundated area increased from 2001 to 2002, CN_a estimates small increases in methane emissions from 2001 to 2002 due to decreases in HR. BGC produces different methane emissions in terms of spatial and temporal trends, probably due to the shift of carbon uptake and release from the tropics to the northern high latitudes as a result of multi-level biogeochemistry in BGC (Koven et al., 2013).
This study suggests that the model-estimated methane budget is sensitive not only to wetland extent (Melton et al., 2013), but also to the details of the carbon model from which methane fluxes are estimated. Accurate simulations of both are necessary to simulate the interannual variation in wetland methane emissions. Further research should focus on regional wetlands (such as high-latitude and tropical wetlands) in order to have a better estimate of the wetland methane budget and its spatial variation. 


\section{Appendix A:}
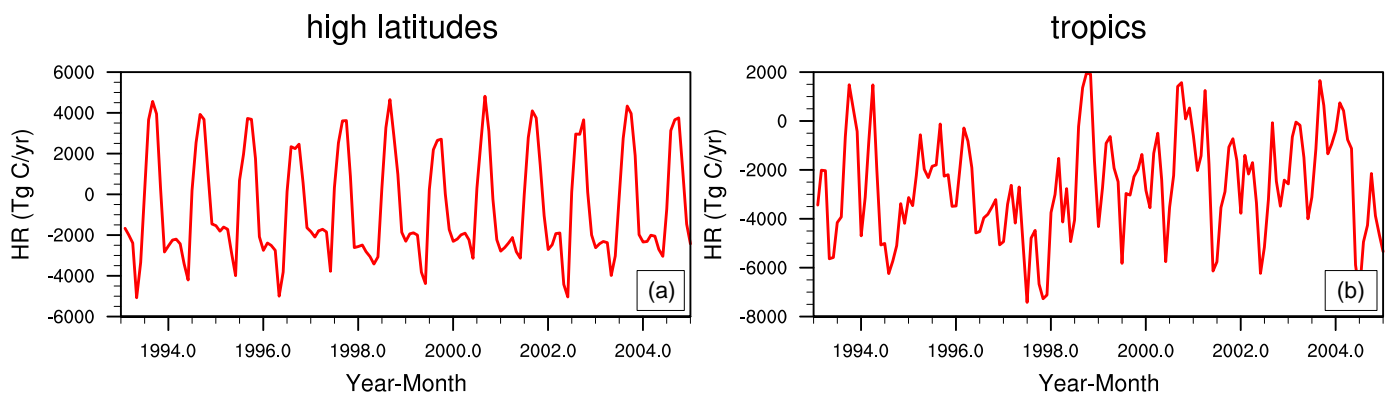

Figure A1. Temporal variation of the difference in HR between CLM4.5 (BGC) and CLM4.0 (CN_a) simulations (CLM4.5 minus CLM4.0) at high latitudes (a) and in tropical regions (b). We use $\mathrm{TgC}_{\mathrm{yr}}^{-1}$ so that it can be easily compared with Fig. 5.

\section{Appendix B:}

high latitudes

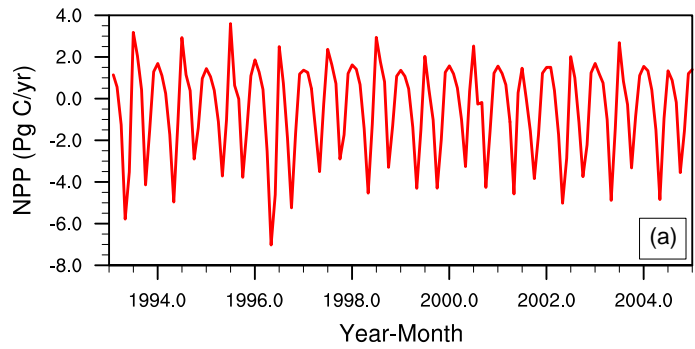

tropics

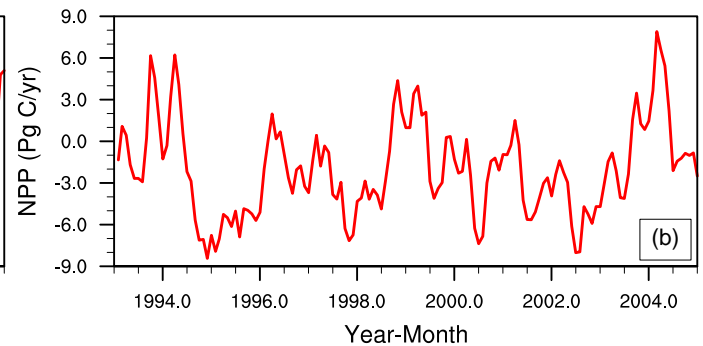

Figure B1. Temporal variation of the difference in NPP between the CLM4.5 (BGC) and CLM4.0 (CN_a) simulations (CLM4.5 minus CLM4.0) at high latitudes (a) and the tropics (b).

\section{Appendix C:}

high latitudes

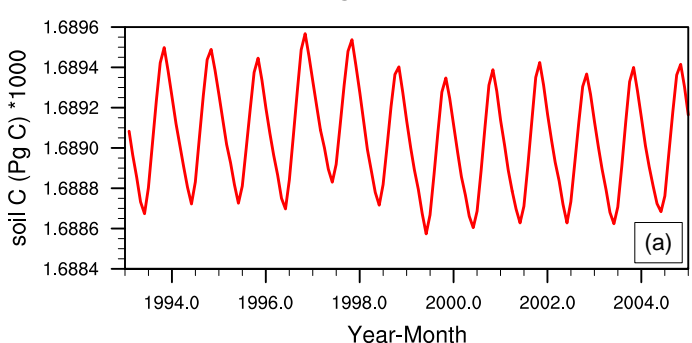

tropics

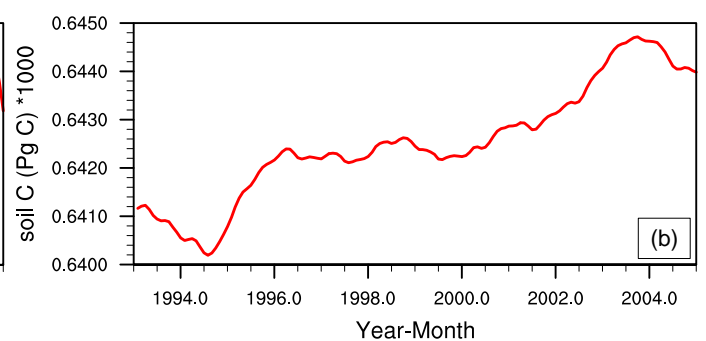

Figure C1. Temporal variation of the difference in soil C between the CLM4.5 (BGC) and CLM4.0 (CN_a) simulations (CLM4.5 minus CLM4.0) at high latitudes (a) and the tropics (b). Please note that the $\mathrm{CN} \_$a model produced substantially less soil $\mathrm{C}$ than the BGC model. In addition, CN_a produced more soil C in the tropics than at high latitudes, while BGC produced more soil C at high latitudes than in the tropics. This result is consistent with Koven et al. (2013). These differences are due to changes in vegetation productivity as a result of soil $\mathrm{N}$ feedback from the revised denitrification in the BGC model. 
Acknowledgements. The authors would like to thank Joe Melton for providing model data sets from the Wetland and Wetland $\mathrm{CH}_{4}$ Inter-comparison of Models Project (WETCHIMP). Part of this work was supported by DOE grant DE-SC0006791.

Edited by: U. Seibt

\section{References}

Bloom, A. A., Palmer, P. I., Fraser, A., Reay, D. S., and Frankenberg, C.: Large-Scale Controls of Methanogenesis Inferred from Methane and Gravity Spaceborne Data, Science, 327, 322-325, doi:10.1126/science.1175176, 2010.

Bloom, A. A., Palmer, P. I., Fraser, A., and Reay, D. S.: Seasonal variability of tropical wetland $\mathrm{CH}_{4}$ emissions: the role of the methanogen-available carbon pool, Biogeosciences, 9, 28212830, doi:10.5194/bg-9-2821-2012, 2012.

Bousquet, P., Ciais, P., Miller, J. B., Dlugokencky, E. J., Hauglustaine, D. A., Prigent, C., Van der Werf, G. R., Peylin, P., Brunke, E. G., Carouge, C., Langenfelds, R. L., Lathiere, J., Papa, F., Ramonet, M., Schmidt, M., Steele, L. P., Tyler, S. C., and White, J.: Contribution of anthropogenic and natural sources to atmospheric methane variability, Nature, 443, 439443, doi:10.1038/Nature05132, 2006.

Butler, J. H., Daube, B. C., Dutton, G. S., Elkins, J. W., Hall, B. D., Hurst, D. F., King, D. B., Kling, E. S., Lafleur, B. G., Lind, J., Lovitz, S., Mondeel, D. J., Montzka, S. A., Moore, F. L., Nance, J. D., Neu, J. L., Romashkin, P. R., Sheffer, A., and Snible, W. J.: Halocarbons and other atmospheric trace species, CMDL Summary Report, edited by: Hompson, T. M., NOAA/US Department of Commerce, Boulder, Colorado, 115-135, 2004.

Chen, Y. H. and Prinn, R. G.: Estimation of atmospheric methane emissions between 1996 and 2001 using a three-dimensional global chemical transport model, J. Geophys. Res.-Atmos., 111, D10307, doi:10.1029/2005JD006058, 2006.

Cunnold, D. M., Steele, L. P., Fraser, P. J., Simmonds, P. G., Prinn, R. G., Weiss, R. F., Porter, L. W., O'Doherty, S., Langenfelds, R. L., Krummel, P. B., Wang, H. J., Emmons, L., Tie, X. X., and Dlugokencky, E. J.: In situ measurements of atmospheric methane at GAGE/AGAGE sites during 1985-2000 and resulting source inferences, J. Geophys. Res.-Atmos., 107, 4225, doi:10.1029/2001JD001226, 2002.

Denman, K. L., Brasseur, G., Chidthaisong, A., Ciais, P., Cox, P. M., Dickinson, R. E., Hauglustaine, D., Heinze, C., Holland, E., Jacob, D., Lohmann, U., Ramachandran, S., da Silva Dias, P. L., Wofsy, S. C., and Zhang, X.: Couplings Between Changes in the Climate System and Biogeochemistry, in: Climate Change 2007: The Physical Science Basis. Contribution of Working Group I to the Fourth Assessment Report of the Intergovernmental Panel on Climate Change, edited by: Solomon, S., Qin, D., Manning, M., Chen, Z., Marquis, M., Averyt, K. B., Tignor, M., and Miller, H. L., Cambridge University Press, Cambridge, United Kingdom and New York, NY, USA, 2007.

Denman, K. L., Brasseur, G., Chidthaisong, A., Ciais, P., Cox, P. M., Dickinson, R. E., Hauglustaine, D., Heinze, C., Holland, E., Jacob, D., Lohmann, U., Ramachandran, S., da Silva Dias, P. L., Wofsy, S. C., and Zhang, X.: Couplings Between Changes in the Climate System and Biogeochemistry. In: Climate Change 2007:
The Physical Science Basis, Contribution of Working Group I to the Fourth Assessment Report of the Intergovernmental Panel on Climate Change, edited by: Solomon, S., Qin, D., Manning, M., Chen, Z., Marquis, M., Averyt, K. B., Tignor, M., and Miller, H. L., Cambridge University Press, Cambridge, United Kingdom and New York, NY, USA, 2007.

Dlugokencky, E. J., Myers, R. C., Lang, P. M., Masarie, K. A., Crotwell, A. M., Thoning, K. W., Hall, B. D., Elkins, J. W., and Steele, L. P.: Conversion of NOAA atmospheric dry air $\mathrm{CH}_{4}$ mole fractions to a gravimetrically prepared standard scale, J. Geophys. Res.-Atmos., 110, D18306, doi:10.1029/2005JD006035, 2005.

Dlugokencky, E. J., Nisbet, E. G., Fisher, R., and Lowry, D.: Global atmospheric methane: budget, changes and dangers, Philos. T. R. Soc. A, 369, 2058-2072, doi:10.1098/rsta.2010.0341, 2011.

Fung, I., John, J., Lerner, J., Matthews, E., Prather, M., Steele, L. P., and Fraser, P. J.: 3-Dimensional Model Synthesis of the Global Methane Cycle, J. Geophys. Res.-Atmos., 96, 1303313065, 1991.

Gent, P. R., Danabasoglu, G., Donner, L. J., Holland, M. M., Hunke, E. C., Jayne, S. R., Lawrence, D. M., Neale, R. B., Rasch, P. J., Vertenstein, M., Worley, P. H., Yang, Z. L., and Zhang, M. H.: The Community Climate System Model Version 4, J. Climate, 24, 4973-4991, 2011.

Giglio, L., Randerson, J. T., van der Werf, G. R., Kasibhatla, P. S., Collatz, G. J., Morton, D. C., and DeFries, R. S.: Assessing variability and long-term trends in burned area by merging multiple satellite fire products, Biogeosciences, 7, 1171-1186, doi:10.5194/bg-7-1171-2010, 2010.

Ito, A. and Inatomi, M.: Use of a process-based model for assessing the methane budgets of global terrestrial ecosystems and evaluation of uncertainty, Biogeosciences, 9, 759-773, doi:10.5194/bg9-759-2012, 2012.

Jauhiainen, J., Takahashi, H., Heikkinen, J. E. P., Martikainen, P. J., and Vasander, H.: Carbon fluxes from a tropical peat swamp forest floor, Glob. Change Biol, 11, 1788-1797, 2005.

Keller, M. M.: Biological sources and sinks of methane in tropical habitats and tropical atmospheric chemistry, $\mathrm{PhD}$, Geological and Geophysical Sciences, Princeton University, Princeton, New Jersey, USA, 216 pp., 1990.

Kirschke, S., Bousquet, P., Ciais, P., Saunois, M., Canadell, J. G., Dlugokencky, E. J., Bergamaschi, P., Bergmann, D., Blake, D. R., Bruhwiler, L., Cameron-Smith, P., Castaldi, S., Chevallier, F., Feng, L., Fraser, A., Heimann, M., Hodson, E. L., Houweling, S., Josse, B., Fraser, P. J., Krummel, P. B., Lamarque, J. F., Langenfelds, R. L., Le Quere, C., Naik, V., O’Doherty, S., Palmer, P. I., Pison, I., Plummer, D., Poulter, B., Prinn, R. G., Rigby, M., Ringeval, B., Santini, M., Schmidt, M., Shindell, D. T., Simpson, I. J., Spahni, R., Steele, L. P., Strode, S. A., Sudo, K., Szopa, S., van der Werf, G. R., Voulgarakis, A., van Weele, M., Weiss, R. F., Williams, J. E., and Zeng, G.: Three decades of global methane sources and sinks, Nat. Geosci., 6, 813-823, 2013.

Kistler, R., Kalnay, E., Collins, W., Saha, S., White, G., Woollen, J., Chelliah, M., Ebisuzaki, W., Kanamitsu, M., Kousky, V., van den Dool, H., Jenne, R., and Fiorino, M.: The NCEP-NCAR 50year reanalysis: Monthly means CD-ROM and documentation, B. Am. Meteorol. Soc., 82, 247-267, 2001.

Koven, C. D., Riley, W. J., Subin, Z. M., Tang, J. Y., Torn, M. S., Collins, W. D., Bonan, G. B., Lawrence, D. M., and Swenson, 
S. C.: The effect of vertically resolved soil biogeochemistry and alternate soil $\mathrm{C}$ and $\mathrm{N}$ models on C dynamics of CLM4, Biogeosciences, 10, 7109-7131, doi:10.5194/bg-10-7109-2013, 2013.

Lamarque, J.-F., Emmons, L. K., Hess, P. G., Kinnison, D. E., Tilmes, S., Vitt, F., Heald, C. L., Holland, E. A., Lauritzen, P. H., Neu, J., Orlando, J. J., Rasch, P. J., and Tyndall, G. K.: CAM-chem: description and evaluation of interactive atmospheric chemistry in the Community Earth System Model, Geosci. Model Dev., 5, 369-411, doi:10.5194/gmd-5-369-2012, 2012

Melton, J. R., Wania, R., Hodson, E. L., Poulter, B., Ringeval, B., Spahni, R., Bohn, T., Avis, C. A., Beerling, D. J., Chen, G., Eliseev, A. V., Denisov, S. N., Hopcroft, P. O., Lettenmaier, D. P., Riley, W. J., Singarayer, J. S., Subin, Z. M., Tian, H., Zürcher, S., Brovkin, V., van Bodegom, P. M., Kleinen, T., Yu, Z. C., and Kaplan, J. O.: Present state of global wetland extent and wetland methane modelling: conclusions from a model intercomparison project (WETCHIMP), Biogeosciences, 10, 753788, doi:10.5194/bg-10-753-2013, 2013.

Meng, L., Hess, P. G. M., Mahowald, N. M., Yavitt, J. B., Riley, W. J., Subin, Z. M., Lawrence, D. M., Swenson, S. C., Jauhiainen, J., and Fuka, D. R.: Sensitivity of wetland methane emissions to model assumptions: application and model testing against site observations, Biogeosciences, 9, 2793-2819, doi:10.5194/bg-92793-2012, 2012.

Mitchell, T. D. and Jones, P. D.: An improved method of constructing a database of monthly climate observations and associated high-resolution grids, Int. J. Climatol., 25, 693-712, 2005.

Montzka, S. A., Krol, M., Dlugokencky, E., Hall, B., Jockel, P., and Lelieveld, J.: Small Interannual Variability of Global Atmospheric Hydroxyl, Science, 331, 67-69, doi:10.1126/Science.1197640, 2011.

Nevison, C. D., Mahowald, N. M., Doney, S. C., Lima, I. D., van der Werf, G. R., Randerson, J. T., Baker, D. F., Kasibhatla, P., and McKinley, G. A.: Contribution of ocean, fossil fuel, land biosphere, and biomass burning carbon fluxes to seasonal and interannual variability in atmospheric $\mathrm{CO}_{2}$, J. Geophys. Res., 113, doi:10.1029/2007JG000408, 2008.

Olivier, J. G. J. and Berdowski, J. J. M.: Global emissions sources and sinks, in: The Climate System, edited by: Berdowski, J., Guicherit, R., and Heij, B. J., A.A.Balkema Publishers, Lisse, the Netherlands, 2001

Papa, F., Prigent, C., Aires, F., Jimenez, C., Rossow, W. B., and Matthews, E.: Interannual variability of surface water extent at the global scale, 1993-2004, J. Geophys. Res.-Atmos., 115, D12111, doi:10.1029/2009JD012674, 2010.

Patra, P. K., Houweling, S., Krol, M., Bousquet, P., Belikov, D., Bergmann, D., Bian, H., Cameron-Smith, P., Chipperfield, M. P., Corbin, K., Fortems-Cheiney, A., Fraser, A., Gloor, E., Hess, P., Ito, A., Kawa, S. R., Law, R. M., Loh, Z., Maksyutov, S., Meng, L., Palmer, P. I., Prinn, R. G., Rigby, M., Saito, R., and Wilson, C.: TransCom model simulations of $\mathrm{CH}_{4}$ and related species: linking transport, surface flux and chemical loss with $\mathrm{CH}_{4}$ variability in the troposphere and lower stratosphere, Atmos. Chem. Phys., 11, 12813-12837, doi:10.5194/acp-11-12813-2011, 2011.

Prigent, C., Papa, F., Aires, F., Rossow, W. B., and Matthews, E.: Global inundation dynamics inferred from multiple satellite observations, 1993-2000, J. Geophys. Res.-Atmos., 112, D12107, doi:10.1029/2006JD007847, 2007.
Qian, T. T., Dai, A., Trenberth, K. E., and Oleson, K. W.: Simulation of global land surface conditions from 1948 to 2004. Part I: Forcing data and evaluations, J. Hydrometeorol., 7, 953-975, 2006.

Rigby, M., Prinn, R. G., Fraser, P. J., Simmonds, P. G., Langenfelds, R. L., Huang, J., Cunnold, D. M., Steele, L. P., Krummel, P. B., Weiss, R. F., O’Doherty, S., Salameh, P. K., Wang, H. J., Harth, C. M., Mühle, J., and Porter, L. W.: Renewed growth of atmospheric methane, Geophys. Res. Lett., 35, L22805, doi:10.1029/2008GL036037, 2008.

Riley, W. J., Subin, Z. M., Lawrence, D. M., Swenson, S. C., Torn, M. S., Meng, L., Mahowald, N. M., and Hess, P.: Barriers to predicting changes in global terrestrial methane fluxes: analyses using CLM4Me, a methane biogeochemistry model integrated in CESM, Biogeosciences, 8, 1925-1953, doi:10.5194/bg-8-19252011, 2011.

Ringeval, B., de Noblet-Ducoudre, N., Ciais, P., Bousquet, P., Prigent, C., Papa, F., and Rossow, W. B.: An attempt to quantify the impact of changes in wetland extent on methane emissions on the seasonal and interannual time scales, Global Biogeochem. Cy., 24, GB2003, doi:10.1029/2008gb003354, 2010.

Shannon, R. D. and White, J. R.: 3-Year Study of Controls on Methane Emissions from 2 Michigan Peatlands, Biogeochemistry, 27, 35-60, 1994.

Spahni, R., Wania, R., Neef, L., van Weele, M., Pison, I., Bousquet, P., Frankenberg, C., Foster, P. N., Joos, F., Prentice, I. C., and van Velthoven, P.: Constraining global methane emissions and uptake by ecosystems, Biogeosciences, 8, 1643-1665, doi:10.5194/bg8-1643-2011, 2011.

Spivakovsky, C. M., Logan, J. A., Montzka, S. A., Balkanski, Y. J., Foreman-Fowler, M., Jones, D. B. A., Horowitz, L. W., Fusco, A. C., Brenninkmeijer, C. A. M., Prather, M. J., Wofsy, S. C., and McElroy, M. B.: Three-dimensional climatological distribution of tropospheric $\mathrm{OH}$ : Update and evaluation, J. Geophys. Res. Atmos., 105, 8931-8980, 2000.

Taylor, K. E.: Summarizing multiple aspects of model performance in a single diagram., J. Geophys. Res.-Atmos., 106, 7183-7192, 2001 .

Thornton, P. E., Lamarque, J. F., Rosenbloom, N. A., and Mahowald, N. M.: Influence of carbon-nitrogen cycle coupling on land model response to $\mathrm{CO}_{2}$ fertilization and climate variability, Global Biogeochem. Cy., 21, Gb4018, doi:10.1029/2006gb002868, 2007.

Thornton, P. E., Doney, S. C., Lindsay, K., Moore, J. K., Mahowald, N., Randerson, J. T., Fung, I., Lamarque, J.-F., Feddema, J. J., and Lee, Y.-H.: Carbon-nitrogen interactions regulate climate-carbon cycle feedbacks: results from an atmosphereocean general circulation model, Biogeosciences, 6, 2099-2120, doi:10.5194/bg-6-2099-2009, 2009.

van der Werf, G. R., Randerson, J. T., Giglio, L., Collatz, G. J., Kasibhatla, P. S., and Arellano Jr., A. F.: Interannual variability in global biomass burning emissions from 1997 to 2004, Atmos. Chem. Phys., 6, 3423-3441, doi:10.5194/acp-6-3423-2006, 2006.

van der Werf, G. R., Randerson, J. T., Giglio, L., Collatz, G. J., Mu, M., Kasibhatla, P. S., Morton, D. C., DeFries, R. S., Jin, Y., and van Leeuwen, T. T.: Global fire emissions and the contribution of deforestation, savanna, forest, agricultural, and peat fires (1997- 
2009), Atmos. Chem. Phys., 10, 11707-11735, doi:10.5194/acp10-11707-2010, 2010.

Wania, R., Ross, I., and Prentice, I. C.: Integrating peatlands and permafrost into a dynamic global vegetation model: 1. Evaluation and sensitivity of physical land surface processes, Global Biogeochem. Cy., 23, GB3014, doi:10.1029/2008GB003412, 2009.

Wania, R., Melton, J. R., Hodson, E. L., Poulter, B., Ringeval, B., Spahni, R., Bohn, T., Avis, C. A., Chen, G., Eliseev, A. V., Hopcroft, P. O., Riley, W. J., Subin, Z. M., Tian, H., van Bodegom, P. M., Kleinen, T., Yu, Z. C., Singarayer, J. S., Zürcher, S., Lettenmaier, D. P., Beerling, D. J., Denisov, S. N., Prigent, C., Papa, F., and Kaplan, J. O.: Present state of global wetland extent and wetland methane modelling: methodology of a model inter-comparison project (WETCHIMP), Geosci. Model Dev., 6, 617-641, doi:10.5194/gmd-6-617-2013, 2013.

Wuebbles, D. J. and Hayhoe, K.: Atmospheric methane and global change, Earth Sci. Rev., 57, 177-210, 2002.
Xu, X. F., Tian, H. Q., Zhang, C., Liu, M. L., Ren, W., Chen, G. S., Lu, C. Q., and Bruhwiler, L.: Attribution of spatial and temporal variations in terrestrial methane flux over North America, Biogeosciences, 7, 3637-3655, doi:10.5194/bg-7-3637-2010, 2010.

Zhao, M. S., and Running, S. W.: Drought-Induced Reduction in Global Terrestrial Net Primary Production from 2000 Through 2009, Science, 329, 940-943, doi:10.1126/Science.1192666, 2010.

Zhao, M. S., Heinsch, F. A., Nemani, R. R., and Running, S. W.: Improvements of the MODIS terrestrial gross and net primary production global data set, Remote Sens. Environ., 95, 164-176, doi:10.1016/j.rse.2004.12.011, 2005.

Zhuang, Q., Melillo, J. M., Kicklighter, D. W., Prinn, R. G., McGuire, A. D., Steudler, P. A., Felzer, B. S., and $\mathrm{Hu}$, S.: Methane fluxes between terrestrial ecosystems and the atmosphere at northern high latitudes during the past century: A retrospective analysis with a process-based biogeochemistry model, Global Biogeochem. Cy., 18, GB3010, doi:10.1029/2004GB002239, 2004. 